\title{
Tarihsel Süreç İçerisinde Üslûba İlişkin Tanım Çabaları ve Bir Tanım Denemesi-II*
}

CELALETTIN DIVLEKCI

AR. GÖR. DR., ANKARA Ü. SOSYAL BIIL., ENST.

e-posta: cdivlekci@hotmail.com

\section{B. İslam Dünyasında}

\section{Klasik Dönem}

Kadim Arap Münekkitleri de üslûp konusunu tartışmış, üslûba ilișkin muayyen bazı tanım çabalarını gündeme getirmiş; en azından dolaylı olarak, temas etmişlerdir. Çağımızdaki bazı eleştirmen ve uzmanların derinliğine sahip olmasalar da, üslûbun tanımı konusunda kendi çaplarında gayret sarf etmişler; anlam çerçevesine dair bir takım sınırlamalar getirmişler ve bu bağlamda çeşitli kavramlar ortaya atmışlardır.

İslam Edebiyat Tarihi'nde üslûpla ilgili meseleleri müstakil olarak konu edinen bir kitap olmadığı gibi; belagatla ilgili eserlerde bu meseleler belirli bir başlık altında ele alınıp işlenmemiştir de! Üslûba ilişkin ip uçlarını belagat, tenkit ve Kur'an'ın i'cazını konu edinen eserlerde lafız-anlam, şekilmazmun veya nazım gibi başlıklar altında ve çoğu kere dağınık bir vaziyette bulabiliriz. ${ }^{1}$

$\mathrm{Bu}$ bağlamda üslûptan bahseden alimlerin, üslûba dair açı bir tanımlama getirdikleri yahut üslûbu oluşturan unsurları detaylı bir şekilde ele aldıklarını söylemek güçtür. Bununla birlikte ortaya koydukları çabaların, yaşadıkları asra göre küçümsenemeyecek boyutta olduğunu

\footnotetext{
Bu makale dergimizin 48. cilt, 2. sayısında yayınlanan yazının devamıdır el-Ma'tûk, "Mefûmu'l-üslûb”, s. 7.
} 
teslim etmek gerekir. Şimdi bu çabaları hicri III. üncü asırdan itibaren kronolojik bir şekilde ele alacağız.

Kuran ve hadislerin dile ilişkin yönü üzerinde duran, Hicrî üçüncü asrın önemli isimlerinden İbn Kuteybe (d.828-ö.879), Kuran'ın üstünlüğünü kavrayabilecek bir kimsenin bir takım nitelikleri hâiz olması gerektiğini düşünür. Bunlar, Kuran'ı çokça tetkik, engin bir bilgi birikimi ve Arapların üslûp(lar) konusundaki farklı ifade tarzları ve yollarını kavramak, şeklindedir. İbn Kuteybe'nin Arapların üslûp konusundaki farklı ifade tarzları ve yollarını kavramak derken ne kast ettiğini şu sözleri daha net ifade etmektedir: "Hatip bir konuda irticalen konuştuğu zaman, sürekli aynı şekilde konuşmaz; kimi zaman sıkıcı olmaması için konuşmasını kısaltır, kimi zaman daha iyi anlaşılması için uzatır. Bazen de pekiştirmek adına tekrara yer verir. Bazen herkesin anlamaması için bazı şeyleri üstü kapalı söyler, bazense ana dili Arapça olmayanların da anlaması için çok açık ifadeler kullanır. Bazen bir şeye işaret edip, kinaye yolunu tercih eder. Hatibin sözle ilgisi, hale, coşkunun dercesine ve makamın yüceliğine göre değișir."

Müellifin ifadesinden anlaşıldığına göre üslûp, konuma, konuya ve konuşmacının kudretine ve sanatçılığına göre değişiklik ve çeşitlilik arz etmektedir. $^{3}$ Açmak gerekirse; İbn Kuteybe'ye göre hatip üslûbunu şekillendirirken, konunun içeriğini, dinleyicinin konumunu ve konu karşısındaki tavrını dikkate alır. Bütün bunları yaparken amacı, herhangi bir iletişim kazasına uğramadan mesajını hedef kitlesine ulaştırmaktır. İbn Kuteybe devamla, Arap Dilinin karakteristik özelliklerinden bahseder; "Arapça'da mecazlar vardır yani söz araçları vardır. Bunların içinde, istiâre, temsil, kalb, takdim-tehir, hazf, tekrar, kinaye, tekil şahsa çoğul şekliyle hitap etmek, çoğul durumda olanlara tekilmiş gibi hitap etmek vs. (...)"4

Üslûbun İslam Kültüründeki iz düşümünü takip eden günümüz araştırmacılarından Muhammed Abdülmuttalib, İbn Kuteybe'nin üslûp anlayışını günümüz diline şu şekilde tercüme eder: "Üslûp, sözle hedeflenen belirli bir amaca ilişkin ifade potansiyellerinin toplamıdır. Sanatkâr, önce içinde hareket edeceği anlam çerçevesini belirler. Daha sonra düşüncelerini içinden geldiği gibi hakkıyla nakledebilmeleri için kelimelerin diziminde kullanacağı münasip tarzı seçer. Bu noktada üslûp makâm ve durumların

2 İbn Kuteybe, Tevilü müşkili'l-Kuran, Tahk. Ahmed Sakr, Dâru ihyâi'l-kütübi'l-Arabiyye, Kahire, 1954, s. 10, 11.

3 Abdulmuttalib, el-Belâga ve'l-üslûbiyye, s. 12.

4 İbn Kuteybe, Tevilü müşkili'l-Kuran, s.16. 
farklılığına, daha sonra söze ilişkin anlam çerçevesine göre ve nihayet sanatkârın sözü belirli bir şekle göre dizme gücüne göre değişir." ${ }^{5}$

Muhammed Abdulmuttalib'e göre, İbn Kuteybe'nin üslûpla edebî eserin bütünü arasındaki ilişkiyi yakaladığı söylenebilir; üslûbu cümleyle sınırlamamış, edebî metni ve içermiş olduğu belagat özelliklerini de içine alacak şekilde geniş tutmuştur. Aynı șekilde, Arapların anlamı dile getirişleriyle üslûp varyasyonları arasında bağlantı kurmuştur. Bütün bunlar, dönemine göre bu alanda yeni bir çaba olarak kabul edilmiștir. ${ }^{6}$

Kısaca, araştırmacıya göre, İbn Kuteybe devrine göre üslûp konusunda önemli sayılabilecek bazı bağlantılar yakalamıştır. Bunları, üslûbun edebî metnin tamamını kuşatan bir olgu olduğu; Arapların anlamı dile getirişleriyle üslûp varyasyonları arasında ilişki kurması ve nihayet üslûbun, konuma, konuya ve konuşmacının kudretine ve sanatçıllğına göre değisşiklik ve çeşitlilik arz ettiğini belirtmesi, şeklinde ifade edebiliriz.

Bu yaklaşım şeklinin doğrusu çok ihtiyatlı olduğunu söyleyemeyiz. Bize göre klasik dönem İslam kültüründe (أساليب القَوْل) denilince, cümle düzeyinde alternatif anlatım teknikleri kast edilmektedir. $\mathrm{Bu}$ ise modern anlamda üslûba tekâbül etmediği gibi, onunla bütün bütün alakasız da değildir. Günümüzdeki anlamıyla üslûp anlatımın bütününü temel alırken, klasik dönemde bahsedilen üslûp(lar) cümleyle sınırlı kalmıştır.

Kanaatimizce İbn Kuteybe'nin bütün bu tespitleri içinde en manidâr olanı, üslûbun Kuran'ı anlamadaki fonksiyonuna işaret etmiş olmasıdır.

Burada dikkat çekilmesi gereken en önemli nokta, üslûbun konuyla, muhatapla ilişkisine dikkat çekildiği halde kaynak birimle olan ilişkisine temas edilmemiş olmasıdır. Bunun sebebi, İslam dünyasında üslûp algısının Kuran eksenli gelişmiş olmasıdır. Kuran üslûbu incelenirken, Kuran'ın ifade formuyla, vahyin sahibi olan Yüce Allah'ın halleri arasında irtibat kurmak muhal olduğu için, üslûp incelemeleri ve algıları, hedef kitlenin durumuyla sınırlı kalmıştır. ${ }^{7}$

IV. Asır alimlerinden Hattâbî (d.931/ö.998) ise, üslûbun temaya göre değişen bir şey olduğunu imâ ederek, şairler arasında yapılacak bir değerlendirmede bunun dikkate alınması gerektiğini vurgular: "Mesela atın vasfı konusunda yazılmış Ebû Davud el-İyâdî ve en-Nâbiğa el-Cadî̀ye ait şiirleri düşünelim ya da şarabı tasvir eden, el-Aşâ ve el-Ahtal'in şiirlerini, yapılan karşılaştırma sonucu bunların tema ve tarzlarında bir diğerinden

5 Muhammed, Abdulmuttalib, “Mefhûmu'l-üslûb fi't-türas”, Fusûl, VII, S. 3, Nisan-Eylül, 1987, s. 47, 48.

Abdulmuttalib, el-Belâga ve'l-üslûbiyye, s. 11.

Abdulmuttalib, "Mefhûmu'l-üslûb fi't-türas", s. 48. 
daha iyi olduğu sonucuna varabiliriz." Hattâbî bu değerlendirmede dikkat edilecek hususları sayarken, şairin üslûbunu (نَمَط كلامِه da dikkate alınması gereken şeyler arasında sayar. ${ }^{8}$

İbn Kuteybe ve Hattâbî her ikisinin düşünce güzergahı Kuran'ın i'câzını değerlendirme istikametinde olsa da, üslûp anlayışları farklıdır. İbn Kuteybe farklı üslûp çeșitleriyle ifade tarzlarının çeşitliliği arasında bağlantı kurarken, Hattâbî üslûpla amaç ya da konu arasında bağlantı kurmuştur. Hattâbîye göre edîbin ele aldığı tema değiştikçe üslûp da değişmiş ve üslûp söz konusu temanın tabiatına göre şekillenmiștir. 0 yüzden şairler arasında yapılacak bir mukayese, bu itibarla ele alınmalı, işledikleri temaların değişmesi halinde her biri kendi konusu içinde değerlendirilmeye tabii tutulmalıdır. ${ }^{9}$

Hicri IV. Asrın sonlarına gelindiğinde aynı şekilde i'câzü'l-Kuran bağlamında üslûp konusuna yer veren bir alim olarak Bâkıllânî (ö.1013)'yi görürüz. Anlaşıldığı kadarılyla Bâkıllânî kendisinden önceki bu iki alimin icaz konusunda söylediklerini etüt etmiş ve özümsemiştir. Bâkıllânî Kuran'ın mucize oluşunu ispat için, indiği dönemdeki edebî türler ve bunların alt kategorileriyle üslûp arasında bağlantı kurar. Kuran'ın, indiği dönemdeki edebî türlerin üslûbuna benzemediğini ortaya koymak sûretiyle Kuran'ın mucize olduğunu göstermeye çalışır. ${ }^{10}$ Müellifin burada kast ettiği, hiç kuşkusuz tür/nevi üslûbudur.

Üslûp konusunda Bâkillânî seleflerinden farklı olarak, üslûpla üslûp sahibinin mizacı arasındaki ilişkiye işaret eder. ${ }^{11}$ Ona göre bir şair ya da yazarın üslûbu onun kaligrafisi gibidir. Diğer kaligrafiler arasından belli olur. ${ }^{12}$ İmzası olmadan da sahibini belli eder. ${ }^{13} \mathrm{O}$ kişilikle üslûp arasında kurduğu ilişkiyi şöyle bir benzetmeyle ortaya koymaya çalışır: "Konuşmayı ve yazıyı resim yapmaya benzetmişler ve şöyle demişlerdir: 'Güler gibi yapan ama aslında ağlayan kimseyi, mahzun olup ağlayanı; ağlar gibi yapan ama aslında güleni, neşeli olup güleni, resmedebilen sanatkâr en usta ressamdır.' Nasıl ki bu misallerin çizimi el hassasiyetine ihtiyaç hissediyorsa, insanın içinden geçenleri tasvir edebilmesi de kişinin dil ve

8 el-Hattâbî, Ebû Süleyman Hamd b. Muhammed, Beyânu i'câzi'l-Kuran, (Selâse resâil fî i'câzi'lKuran içinde), Tahk. Muhammed Halefullah- Muahammed Zalûl Selam, Dâru'l-me'arif, Kahire 1968, s. 65, 66

9 Abdulmuttalib, el-Belâga ve'l-üslûbiyye, s. 14, 15.

10 Bâkıllânî, I'câzü'l-Kuran, Tahk.Seyyid Ahmed Sakr, Kahire, Daru'l-meârif, 1963, s. 120-122. Krş. Abdulmuttalib, el-Belâga ve'l-üslûbiyye, s. 15, 16.

1 Abdülmuttalib, 'Mefhûmu'l-üslûb fi'türâs", s. 49; el-Ma'tûk, "Mefûmu'l-üslûb”, s. 8.

12 Bâkıllânî, I'câzü'l-Kuran, s. 120.

13 Krş. Halil, el-Üslûbiyye ve nazariyyetü'n-nass, s. 24. 
mizaç bakımından hassas olmasına ihtiyaç hisseder."14 İbn Kuteybe'nin üslûp anlayışına temas ederken İslam alimlerinin üslûp telakkîsinin Kuran çerçevesi içinde gelişmesinden dolayı sadece üslûp-muhatap ilişkisiyle sinırlı olarak şekillendiğini belirtmiștik. Hal bu ki Bâkıllânî’nin bu açıklamasında, kişiliğin etkisine de işaret edilmektedir. Bu farklılığın sırrını, Bâkıllânî'nin anlatmak istediklerini, İslam kültürüne oldukça uzak, resim sanatının incelikleriyle anlatmasında aramak gerektiğini düşünmekteyiz. Kanaatimizce müellif, 'benzetmişler' diyerek isim vermekten kaçındığı, üslûpla kişilik arasında bağ kuran yabancı bir kültürün mensuplarına atıfta bulunmaktadır.

Konu üslûpla kişilik arasındaki ilişkiden açılmışken, referans metnin imkanlarını zorlamak pahasına da olsa, kimi araştırmacıların Câhız (d.775ö.868)'ın bu tür bir ilişkiye atıfta bulunduğunu iddia ettiklerini belirtelim. ${ }^{15}$ Câhız, yazarın çocuğuyla eseri arasında yapmış olduğu mukayesede, sözle, söz sahibinin varlığı arasındaki ontolojik ilişkiden bahseder: "İdrak sahibi kimse, tetebbu sahibi değilse çoğu zaman [kitapla] çocuğuyla yaşadiğı şeyleri yaşar. Başkasina çirkin gelen çocuğunun bir yönü, onun gözünde güzeldir. Bilinmelidir ki yazarın lafzı, aidiyet bakımından kendisine çocuğundan daha yakındır. Tavrı ile olan akrabalı̆̆ çocuğuyla olan akrabalığından daha ötedir. Cü̈nkü tavrı, kendisinden var ettiği ve bizatihi kendisi var ettiği, kendi cevherinden ayrılan, kendisinden olan bir şeydir. Cocuksa sadece sümkürülen bir sümük ya da dışarı atılan bir balgam gibidir. Vücudun bir parçasından senin bir parçan olmayan bir şey çıartmanla, sen ortaya koyuncaya kadar var olmayan bir tavrı ortaya koyman aynı şey değildir. Bu yüzden kişinin şiirine, sözüne, kitaplarına olan tutkunluğu, tüm nimetlerine olan tutkunluğun üstündedir. ${ }^{\prime \prime 6}$

Metnin bağlamından anlaşıldığı kadarıyla Câhız, 'yazma eylemini' 'tavır' dediği şeyin bir parçası, bir uzantısı olarak görmektedir.

Matûk'a göre Câhız burada 'tavır' kavramını, muhtemelen üslûpla eşanlamlı olarak kullanmıştır. ${ }^{17}$ Bu tespit doğru kabul edildiği takdirde, ortaya attığı bu kavram, inşâ sahibinin şahsiyet ve ruhunu kısmen ya da tamamen temsil etmektedir. Çünkü 'tavır', ona göre, bütün unsurlarılya kişinin bir parçasıdır; onun var etmesidir ve tavır kişiye, sulbünden gelen çocuğundan daha yakındır. Matuk, bir adım daha ileri gider ve Câhız'ın

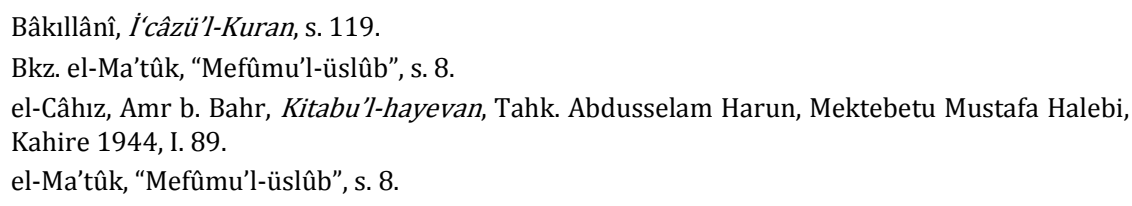


üslûp-kişilik ilişkisini Buffon'dan daha önce dile getirdiğini ileri sürer. ${ }^{18}$ Kanaatimizce bu yorum, gerçekçi olmaktan uzak olup, tercümesini nakletmiş olduğumuz referans metnin anlatım imkanlarını zorlayan bir mahiyet arz etmektedir.

Bâkıllânî bir yazarı diğerinden, bir şairi bir diğer şairden ayırt eden ferdi üslûptan bahsederken, bazı şair ve yazarların üslûp bakımından birbirlerine yakın olduklarını da göz ardı etmez. Bâkıllânı̂’nin, günümüzde 'dönem üslûb'u dediğimiz, bir dönemin yazarını bir başka dönem yazarından ayırt eden yazım tarzına da temas ettiğini görmekteyiz: ${ }^{19}$ "Günümüzde yaşayan birisi için, Abdülhamid dönemi risaleleriyle, sonrası döneme ait risaleler arasındaki ayrım gayet açıktır. Öyle ki aynı dönemin yazarlarının; İbnü'l-Amid ile muasırlarının veya onun takipçisi konumunda olanların yazdıklarını ayırt edemeyebilir. Aynı dönem içerisindeki yazarlar, karşllıkl etkileme ve etkilenme, bilgi ve tecrübe alışverişi sayesinde birbirlerine yakın üslûplara sahip olabilir ve böylece yazılarını bir başka dönemdeki yazarın yazılardan ayırt eden bir tarz ortaya çıkmış olur."zo

Görüldügü üzere, Bâkıllânî ferdî üslûbun yanı sıra dönem üslûbuna da temas ediyor, hatta dönem üslûbunu ortaya çıkaran etkenleri de ortaya koyuyor. Bâkıllânî'nin ferdi üslûba sıkça atıfta bulunmasının anlamıİbrahim Halil'e göre- bu vesileyle herkesin kendisine göre bir üslûbu olduğu, üslûbun kişinin ele aldığı konuya göre değişiklik arz eden ve insanın mizacından etkilenmeye açık olan bir olgu olduğu sonucuna ulaşmaktır. ${ }^{21}$ Bâkıllânî'nin üslûp çerçevesindeki görüşlerine son vermeden önce, çağdaş Batılı araştırmacılardan Graham Hough'un kelime bağlam ilişkisine dair görüşüyle birebir örtüşen aşağıdaki tespitine yer vermek istiyoruz: Hough'a göre, "Siirin belirli bir misrasında büyülü ve etkileyici olan bir kelime başka bir cümlede çok cansız durabilir; bir bağlamda çok acemice duran bir yapı, başka bir bağlamda ya da cümlede çok güçlü bir açıklayıcı amaca hizmet edebilir. Anlamın felsefesine ve yaratıcı sürecin psikolojisine dair teorimiz ne olursa olsun, üslûp tahlilinin temel aldığı/ilgilendiği olgu budur." 22

Konuyla ilgili Bakıllânî̀nin tespitleri de şu şekildedir:"Muhakkak ki kelimenin seçimi ve onun bağlam bakımından en uygun yere konulması, belagatın temeli, anlatımın zirvesidir. Zira bir yere bazen iki kelimeden sadece birisi uygun düşebilir. Birisinin ayağının kaymadığı, hatta kök saldığı

el-Ma'tûk, "Mefûmu'l-üslûb", s. 8.

Halil, el-Üslûbiyye ve nazariyyeti'n-nass, s. 25.

Bâkıllânî, I'câzü'l-Kur'an, s. 121, 122.

Halil, el-Üslûbiyye ve nazariyyetü'n-nass, s.26.

Hough, Style and Stylistics, s. 12. 
bir yerde, diğerininki kayabilir. Olması gerektiği yere konulmuş kelimenin, bulunduğu yere karşı çıkmadığını, (kaçacak gibi durmadığını) görürsün. Hal bu ki onun yerine diğeri konulmuş olsaydı, bulunduğu yerden memnun olmadığını, kaçmak isteyeceği bir yere konulmuş gibi durduğunu müşahede ederdin." 23 Aralarındaki tarihi, coğrafi, kültürel ve ideolojik mesafeye rağmen hicri IV. Asırda yaşamış bir alimle Batılı bir araștırmacının aynı yerde buluşmaları oldukça düşündürücüdür. Üstelik zaman zaman işaret edeceğimiz üzere bu bir istisna da değildir.

Hicri V. Asrın üslûp konusunda özellikle de Kuran üslûbu konusunda en dikkat çeken isimi, hiç kuşkusuz, Abdülkâhir Cürcânî (ö.1078)'dir. ${ }^{24}$ Cürcânlı bu alim neredeyse ismiyle özdeş hale gelen nazım teorisiyle, hem Arap Dili Belagatı konusunda hem de Kuran'ın üslûp teorisi konusunda çığır açmıştır. Cürcânî̀ye göre; "üslûp, nazmın bir nevi ve nazımda bir yoldur."25 Öyleyse, nazmın tanımını vermek, bir yerde Cürcânîye göre üslûbun tanımını belirlemek olacaktır. Nazım, sözün, ifade edilmek istenen anlama uygun olacak şekilde tasarlanmak suretiyle düzenlenmesidir. ${ }^{26} \mathrm{Bu}$ durumda, nazımda iki unsur bulunmaktadır: 'Anlatmak istediğimiz anlam' ve 'bu anlamı kendisiyle ifade ettiğimiz lafızlar'. ${ }^{27}$ İfade etmek istediğimiz

23 Bâkıllânî, I'câzü'l-Kuran, s. 220.

24 Hayatı hakkında fazla bir bilgi bulunmayan Cürcânî Ortaçağ’da önemli kültür merkezlerinden birisi olan Cürcân'da doğdu ve bütün hayatını orada geçirdi. Arap dilbilgisini Muhammed b. Hasen el-Fârisî'den okudu. Ayrıca Kadı Ebu'l-Hasen Ali b. Abdülaziz'den ders aldığı da rivayet edilmektedir. Tahsil döneminden sonra Cürcân'da ders vermeye başladı. Şöhreti kısa zamanda yayıldı. İran asıllı olmasına rağmen hiçbir eserini Farsça yazmadı. Arap Dilinin bütün inceliklerine vakıf olması ve nahvi bir Arap mantığı çerçevesinde ele alması sebebiyle 'imamü'n-nühat' olarak anıldı. Belagat konusunda düşünceye dayalı bir tenkit zihniyetine sahip olması onu emsallerinden farklı bir isim haline getirmiștir. Bu yönüyle de 'șeyhu'lbelaga' olarak kabul edilmiştir. Başlıca eserleri: Delâilu'l-i'câz, Esâru'l-belaga, Kitâbü'I-cümel, Kitâbü'I-muktesit'dir. Geniș bilgi için bkz. Nasrullah Hacımüftüoğlu, "Cürcânî", DİA, I. 247, 248.

25 Cürcanî, Abdülkahir, Delâilü' '-i'câz, Tah. M. Muhammed Şakir, Mektebetu'l-hancı, Kahire 2004, s. $468,469$.

26 Hasen Abbâs, Fadl, el-Belâga fünûnüha ve efnânuha, Dâru'l-Furkan, Amman 1997, I. 85. Nazm Teorisinin ilmî değerine dair yapılmış bir araştırma için bkz. Muhammed Murâd, Velîd, Nazariyyetu'n-nazm, Dâru'l-fikr, Dımaşk 1983.

27 Lafız kelimesinin Türkçe'mizdeki karşılı̆̆ı, buradaki teknik kullanımı tam olarak karșllamamaktadır. Arapça Sözlükler, yaygın olan kullanım șekliyle, lafzın kelimeyle eșanlamlı olduğu konusunda hemfikirdirler. Buna göre, 'dilin lafızlarını saydık' cümlesiyle, 'kelimelerini saydık' cümlesi arasında fark yoktur. Bununla birlikte, nahivciler kitaplarında 'lafız', 'kelime' ve 'kavl' kelimelerini uzun uzadıya açıklayarak, aralarında bir ayrıma gitmeye çalışmışlardır. Yaptıkları açıklamalardan, 'lafız'dan, telaffuz ameliyesi, sesin çıkış keyfiyeti ve buna dil ve dudak hareketlerinin eșlik etmesini, anladıklarını görüyoruz. Telaffuz edilen seslerle, bu seslerin gösterdikleri anlam ilişkilendirildiği zaman, onların görüşüne göre 'kelime' oluşur. Yani kelime lafızdan daha özeldir. Zira kelime, bir anlamı gösteren sesler topluluğudur. (Bkz. Enis, İbrahim, Delâletü'l-elfâz, Mektebetü'l-anglo'l-Mısrıye, Kahire 1963, s. 38.) Daha açı bir ifadeyle; lafız insanın ağzından çıkan ses birliğidir. Manalı olursa kelime adını alır. Konu ile 
anlam değişince, kaçınılmaz olarak lafızlar da- aynı unsurlar içinde kalarak değişecektir. ${ }^{28}$

Cürcânî nazımın mahiyetinin daha iyi anlaşılması için, nazımla, dokuma, dövme gibi motif içeren şeyler arasında bir benzerlik kurarak nazmın iç yapısını/düzenini açıklamaya çalışır. Buna göre nazım, zihindeki anlatılmak istenilen düşüncenin ifade edilmesi için, her kelimenin, bulunduğu yere konulmasını gerektirecek bir sebebin mevcut olması ve birinin yerine başkasının konmasının doğru olmayacak şekilde olması demektir. ${ }^{29}$

Cürcânî'nin nazım teorisine giriş sadedinde ortaya atığı ilk mesele, 'dilsöz' ayrımı meselesidir. Cürcânîye göre söz, sentaks ilişkileri vasıtasıyla lafızların birbirleriyle ilintili olmalarıdır. Sentaksa ilişkin bu bağlantılar, tüm öğeleri bir bağlam içine sokar. Sentaks Arapların manzum eserlerinde olduğu gibi, mensur eserlerinde de olan, herkesim tarafından bilinen bir şey olduğuna göre, bir sözü diğerinden farklı kılan nedir? Niçin bir sözü, fasih, açık, olağanüstü olarak nitelerken, bir başka sözü bu şekilde görmeyiz? Haddizatında Kuran sentaks kaidelerinin tanzim ettiği bir takım kelimelerden ve kelimeler arası bu ilişkiden ortaya çıkan anlamlardan oluşan bir sözdür. Kuran, Arapların kullandığı kelimelerin dışında bir takım kelimelerle, onların kullandığı sentaks kurallarının dışında bir kuralla nazil olmadığına göre, Kuran'ı mucize yapan nedir? 30

Dil, öyleyse, toplumun her kesiminin ortak olduğu bir şeydir. Söz ise, bir insanın sözünü diğerininkinden farklı hale getirecek ferdî bir unsura sahiptir. Bu yüzden Cürcânîye göre; dili, kelimeleri ve kaideleri yönüyle bilmek, şiirde ve sözde kaliteye götürmez. Eskilerin şiirini, dili daha iyi bildikleri gerekçesiyle yenilerin şiirine tercih edenler ya da Klasik Dönem şairlerin şiirini, Klasik Devreden sonraki (müvelledin) şairlerin şiirine, “Arapça'ya sonradan girmişlerdir; Araplara sonradan giren unsurlar aslî unsurlar gibi değildir" gerekçesiyle, tercih edenler büyük bir hata içindedir.

ilgili kaynaklarda lafzın (teklik hâlinde) birden fazla kelime, ibare için de kullanıldığını görüyoruz. Kısaca lafız, bir kavramı, duygu ve düşünceyi gösteren/dâldir. Bu lafzın gösterdiği kavram ise gösterilen/medlûldür. (Bkz. Saraç,Yekta, Klâsik Edebiyat Bilgisi, Gökkubbe, İstanbul 2004, s. 55.) Lafız-çağrışım ilişkisi bağlamında, lafzın, dinleyicinin tecrübelerinden ya da hayatta karşılaştığı maddi manevi varlıklardan elde ettiği formları tedâî ettiren sese ilişkin yapı olduğu da belirtilmiștir. bkz. Murâd, Nazariyyetu'n-nazm, s.166.

Cürcanî, Delâilü'l-i'câz, s. 49. Krş. Murâd, Nazariyyetu'n-nazm, s. 156.

Halil, el-Üslûbiyye ve nazariyyetu'n-nass, s. 35. 
Maharet dilin kelime ve kurallarını bilmekte değil, bunları kullanma ve tercih şeklindedir. ${ }^{31}$

Cürcânî, modern dilbilimin keșiflerinden kabul edilen, dilde toplumsal olanla ferdi olan arasındaki bağlantıyı yakalamıştır. Dilbilimin kurucusu, F. De Saussure (d.1857-ö.1913)'ün seslendirdiği ' dil ile 'söZz arasındaki ayrım, müellifimizin yapmış olduğu bu ayrımdan başkası değildir. Nitekim, Saussure şöyle der: "Dil mahiyeti itibariyle, fertten bağımsız toplumsal bir sistemdir. Söz ise, dile göre ferdi bir uygulamadir. Bunun anlamı, dil toplumsal bir düzenleme ve kodlar bütünüyken, söz ise bireysel bir eylemdir." "32 Dil ile söz arasındaki ayrım, modern dilbilimde farklı isimler altında kendisine karşılık bulmuştur: Guillanume'de 'languge' ve 'et discourse'; Chomsky'de 'competnce' ve 'performance' Jakobson'da 'code' ve 'message'. ${ }^{33}$

Cürcânî Delâilu'l-i'câz adlı eserinde sözlük anlamı olarak cümle içindeki kelimelerin dizimiyle, kelimeyi oluşturan harflerin dizimini karşılaştırır. Ona göre harflerin dizimi dilin vâzıı o şekilde koyduğu için öyle olmuştur. Anlamın harflerin diziminde hareket noktası olmak gibi bir durumu yoktur. Hal bu ki kelimelerin cümle içindeki dizimi böyle değildir. "Cünkü kelimelerin diziminde anlamın izleri takip edilir ve kelimeler cümle içinde, anlamın zihindeki yapısına göre düzenlenir."

"O takdirde burada bahis konusu olan nazım, kendisinde kelimelerin birbiriyle olan ilişkileri dikkate alınarak dizilen bir yapı olup, bir şeyin gelişi güzel, rasgele başka bir şeye eklemlendiği türden bir dizim değildir. Aynı şekilde nazım, alimlere göre bir takım parçalara benzer ki, her birinin, 'dokuma', 'telif', 'dövme' ve 'süsleme' gibi [bulundukları kompozisyon içinde] birbiriyle olan karşıllıklı ilişsileri bakımından mevcut yerlerinde bulunmalarını gerekli kılan bir sebebi vardır. Bu durum bilindiği zaman, nazımdan maksadın telaffuzda ortaya çıkan bir dizim olmadı̆̆ı, daha doğrusu anlamların aklın iktiza ettiği şekliyle bir araya geldiği ve koordine olduğu bilinir. Cümle içi unsurların birbiriyle olan ilişkisinin dikkate alındığı ve nazmın 'dövmeye', 'süslemeye' ve 'desenli elbiseye' benzeyen bir tarafı ve bütün bu benzerlikle kasıt edilenin tasarım olduğu, dahası bizim anlamlarını bir tarafa bıraktı̆̆ımız zaman, birbiriyle ilişskili iki kelimenin ilişkilerinin dikkate alınmayacağında kuşku yokken, kelimelerin diziminin rasgele olduğu nasıl düşünülebilir?’34

Cürcanî, Delâilü'l-i'câz, s. 249. Krş. Halil, el-Üslûbiyye ve nazariyyeti'n-nass, s. 35.

Halil, el-Üslûbiyye ve nazariyyetu'n-nass, s. 36.

Halil, el-Üslûbiyye ve nazariyyetu'n-nass, s. 36.

Cürcanî, Delâilüll-i'câz, s. 49, 50. 
Buna göre üslûp, "önce anlamların zihindeki diziliş, bir araya getiriliş ya da tasavvurudur. Daha sonraki aşama ise bunları ifade etmek ve şekillendirmek için, dilin sözlük ve sentaks imkanlarını değerlendirmektir." ${ }^{\prime 35}$

Teorisyenin üslûpla olan ilişkisi bununla da sınırlı değildir. Eserinde sergilediği üslûpla ilgili kimi yaklaşımlar, başlı bașına inceleme konusu olacak kadar derinliklidir. Örneğin Pierre Guiraud gibi modern anlam bilimcilerin ortaya attığı; "kelimelerin anlamaları yoktur, ancak kullanımları vardır."36 şeklindeki yaklaşıma benzer yaklaşımlar sergiler: "Kelime dizimi değiștiği zaman, daha önce beyan edildiği üzere, anlamın da değişmesi gerekir." 37 "Kelimeler tek başına sentaks dizgesinin dışında kaldığı zaman, düşüncenin kelimeyle alakasının kalmadı̆̆ının bilinmesi ve hatırlanması gerekir. Bir fiilin bir ismi obje olarak almaksızın anlam ifade edeceğini, aynı şekilde, bir eyleme konu olmaksızın bir ismin bir anlam taşıyacağını düşünmek mümkün değildir."38 Kısaca, Cürcânî bir kelimenin anlamının, içinde yer alacağı metinde diğer kelimelerle kuracağı ilişkiden kaynaklanacağını belirtmektedir. Aynı şekilde nazım konusunu işlerken, modern üslûp incelemelerinde hareket noktası olan, kendisinin 'ma'ne'lma'na'adını verdiği 'yan anlam'konusuna da temas eder. ${ }^{39}$

Son olarak Cürcânî'nin nazım, üslûp ve bunların dil, sentaks ve belagatla olan ilişkisine dair görüşleri çağdaş yapısalcı ve yenilikçi üslûpbilimcilerin edebiyat eleştirisi ve retoriğe dair görüşleriyle birebir örtüștüğünü belirtelim. ${ }^{40}$

Fahreddin er-Râzî (ö.1210) de edebî türle üslûp arasında bağlantı kuranlar arasındadır. ${ }^{41}$ Hatta Abdülmuttalib'in tespitine göre; "Râzî üslûpla tür arasında bağlantı kurmakla kalmamış, üslûpla üslûp sahibi arasında da ilişki kurmuştur. Yazara göre, şayet Râzî̀nin bu tespiti kendisinden sonra geliştirilmiş olsaydı, kuşkusuz kadim tenkit incelemeleri çok önemli bir

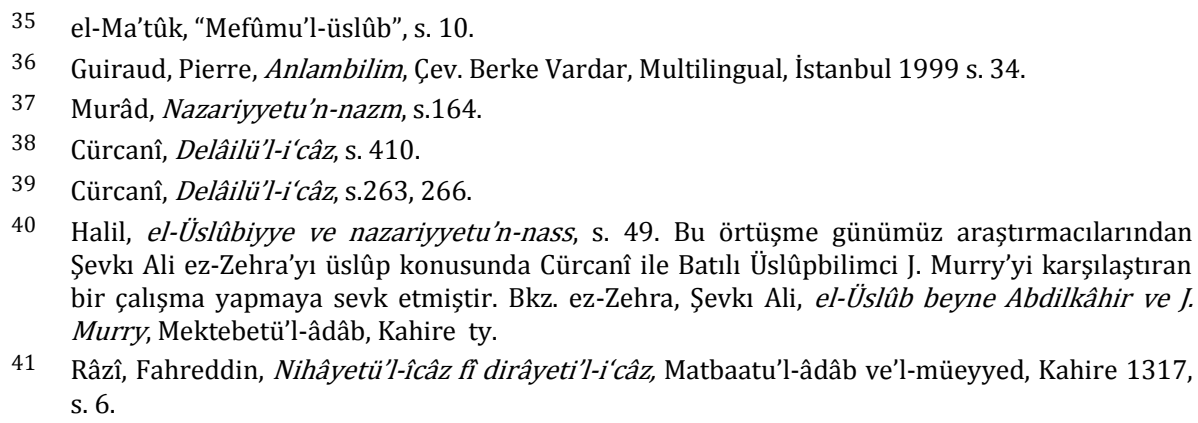

Halil, el-Üslûbiyye ve nazariyyetu'n-nass, s. 49. Bu örtüşme günümüz araștırmacılarından Şevkı Ali ez-Zehra'yı üslûp konusunda Cürcanî ile Batılı Üslûpbilimci J. Murry’yi karșıllaștıran bir çalıșma yapmaya sevk etmiştir. Bkz. ez-Zehra, Şevkı Ali, el-Üslûb beyne Abdilkâhir ve J. Murry, Mektebetü'l-âdâb, Kahire ty.

41 Râzî, Fahreddin, Nihâyetü'l-îcâz fî dirâyeti'l-i'câz, Matbaatu'l-âdâb ve'l-müeyyed, Kahire 1317, s. 6 . 
ivme kazanmış olacaktı." ${ }^{2}$ Râzî̀nin, üslûpla inşâ sahibi arasında kurmuş olduğu ilişkinin, üslûpla edebî tür arasında kurmuş olduğu ilişki kadar net ve açık olduğunu söylemek mümkün değildir. ${ }^{33}$ Öte yandan bu yaklaşımı, Bakıllânî gibi Kuran'ın icazını, üslûbunun farklı oluşuna; şiir, hitabet, mektup gibi indiği dönemdeki edebî türlerin üslûbuna benzememesine bağlamak isteyenlerin tezlerini çürütmeye yönelik olduğu da söylenebilir. Râzî kısaca şunu demek istemektedir: Üslûpta farklı olmak, emsalsiz olmak demekse, her edebî tür hatta her üslûp aynı şekilde bir diğerinden farklıdır ve emsalsizdir. Dolayısıyla Kuran üslûbu yönüyle mucize değildir. ${ }^{44}$

Râzî’nin 'Kuran üslûbu yönünden mucize değildir' derken, kast ettiği şeyin, nazmın bir türü olan üslûp olmadığını Mefâtihu'l-ğayb adlı tefsirinde Bakara Suresi 285. inci ayeti meyanında vermiş olduğu izahattan anlıyoruz: "İște kim bu surenin nazmı, yani kelamın dizimindeki incelikler ve tertibinin eşsizliği üzerinde iyiden iyiye düşünürse, Kuran'ın lafızlarının fesahat ve manalarının üstünlügü bakımından mucize olduğunu anlar. 'Kuran üslûbu mucizedir' diyenler galiba bunu kast etmektedirler." 45

Üslûp kavramı, İslam Coğrafyasının Mağrip bölgesinde kendisine mümbit bir alan bulmuştur. $\mathrm{Bu}$ coğrafyadaki edebiyat münekkitleri önlerinde, Doğu'dan ve Yunan Kültüründen beslenen geniş bir kültür havzası buldular. Bu ortamda yetişen bir edebiyat teorisyeni Hâzim elKartâcennî (d.1211-ö.1285) üslûba dair, seleflerine klyasla daha kapsaml, daha kuşatıcı bir inceleme ortaya koydu: Minhâcü'l-büleğâ ve sirâcü'lüdebâ. el-Kartâcennî söz konusu eserinde, uzmanların belirttiği kadarıyla, üslûp incelemesine dair özel bir metot geliştirdi. Esere dair okumalardan anlaşıldığı kadarıyla, el-Kartâcennî Cürcânîyi okumuş, onun nazım anlayışını içselleştirmiş ve bu kavramı üslûp kavramının karşısına koymuştur. ${ }^{46}$

Burada üzerinde dikkatle durulması gereken nokta, el-Kartâcennî̀nin nazmı baştan sona bütün bir ibdâ işlemini kuşatacak bir hale getirmiş olmasıdır. Böylece el-Kartâcennî, Cürcânî́nin cümle ya da cümle hükmündeki dil birimlerindeki sentaks ilişkileri temeline oturan, cümleyle sınırlı nazım incelemesini, hapis olduğu sınırların dışına çıkartmıştır. elKartâcennî üslûp anlayıșını, bir yönüyle Aristo'nun edebî esere bir bütün

42 Abdulmuttalib, el-Belâga ve'l-üslûbiyye, s.17. Krş. Abdulmuttalib, "Mefhûmu'l-üslûb fi't-türas", s. 51,52 .

43 Benzeri bir değerlendirme için bkz. el-Ma'tûk, "Mefûmu'l-üslûb”, s. 8.

44 Râzî, Nihâyetü'l-îcâz, s. 6.

45 Râzî, Fahreddin, Mefâtihu'l-ğayb, Dâru'l-kütübi'l-ilmiyye, Beyrut 1990, IV. 112.

46 Abdulmuttalib, el-Belâga ve'l-üslûbiyye, s. 27. 
olarak bakan yaklaşımından, diğer yönüyle Cürcânî'nin nazım anlayışından etkilenerek olușturmuştur. ${ }^{47}$

Kartacalı Hâzim, Arap șiir biçimi olan kasideyi ilk defa, gönümüzdeki 'makro yapı'ya tekabül eden 'fasıllara' ayırıp, bunların şiirin iç yapısında bir değeri olduğunu iddia etmiştir. Buna göre fasıllar, kasidedeki bazı beyitlerin bir tema öbeği etrafında, diğer öbeklerden bağımsız olacak şekilde bir araya gelmesidir. Yine kasidenin matla'ı ile makta' ${ }^{48}$ arasındaki bağlantıyı ilk yakalayan teorisyendir. Böylece el-Kartâcennî kasidenin iç yapısındaki bütünlügü, geliştirmiş olduğu yaklaşımla ortaya koymuştur. ${ }^{49}$

el-Kartâcennî şiir üslûplarını bilmenin yollarından bahsederken şöyle der: "Şiir üslûpları, şairin sülûk ettiği şiir yoluna [poetikasına], ruhların, sertliğin engebeliğine çıkışı yahut yumuşaklığın düzlüğüne inişi ya da sertlikle yumuşaklık arasında orta bir yol tutuşuna göre çeşitlilik arz eder."

"Öyle söz vardır ki, zayıf, fazlasıyla şefkatli ruhların amaçlarına uygundur. Öyle sözler de vardır ki, olayları çok fazla önemsemeyen, sert ruhların amaçlarına uygundur. Yine öyle sözler vardır ki, her iki gurubun sözünden de uzak duran, samimi içten ruhlara uygundur." Daha sonra bir değerlendirme yaparak şöyle der: "Üslûp konusundaki bu bölümlere göre, sözün üç üslûbu vardır. Söz bu üç üslûp türü içerisinde kolay ve zor oluşuna göre on kısma ayrılır. Bu kısımlar konusunda insanlar temayüllerine, temayülleri de tabiatlarına göre farklılık arz eder. Bu bölümler:

\section{Sözün salt yumuşaklık üzere bina edilmesi.}

2. Sözün salt sertlik üzere bina edilmesi."50

Hâzim el-Kartâcennî üslûbu, "anlama ilişkin unsurların bir araya gelmesiyle oluşan durum." 51 şeklinde niteleyerek nazımla üslûp arasında ayrıma gitmiştir. Onun anlayışına göre nazım ise; lafza ilişkin unsurların bir araya gelmesi ya da ibarenin kalıba konmasıdır. Anlaşılan o ki, söylemin lafız boyutuna 'nazım', anlam boyutuna ise 'üslûp' adını vermiştir. Böylece el-Kartâcennî üslûp kavramı konusunda Cürcânî'den ayrılmıştır. Müellifin orijinal fikirler serdettiği Minhâcü'l-Büleğâ'sı çeşitli sebeplerden dolayı

\footnotetext{
Abdulmuttalib, el-Belâga ve'l-üslûbiyye, s. 27.

48 Matla': Bir manzumenin ilk musarra' (mısralı kafiyeli) beytidir. Makta' ise, bir manzumenin sonunda olan beyittir. Bu tabir çoğunlukla gazel için kullanılır. Bkz. Muallim Naci, Istılâhât-ı Edebiye, (Haz. M. A. Yekta Saraç), Gökkubbe, İstanbul 2004, s.104. 
Doğu'da hak ettiği ilgiyi görmemiştir.52 Mağrip'te ise selefi İbn Haldun üzerinde etkili olmuştur.

İbn Haldun (d.1332-ö.1406), denilebilir ki üslûbun anlamını, kendisinden önceki münekkit ve araștırmacılara göre, en iyi anlayan ve kavramın anlam alanını en ince ve net bir şekilde belirleyen düşünürdür. Aynı şekilde, görüldüğü kadarıyla, kavramın uygulanabilirliği ve benimsenmesi noktasında en az tereddüt yaşayanlardandır.

Müellif, Mukaddime'sinde şiir ve edebiyattan bahsederken şöyle der:"Şimdi üslûbun şiir sanatıyla meşgul olan kimseler nezdindeki seyrine ve onlara göre ne anlama geldiğine yer verelim.

Bilindiği üzere üslûp, kelime terkiplerinin dokunduğu bir tezgah ya da içi boşaltılıp doldurulan bir kerpiç kalıbıdır. Üslûbun fonksiyon alanı; herhangi bir özel terkibe uyması bakımından, genel geçer anlamda kelime/terkip dizgesine ilişkin zihinsel forumlardır. Bu formları zihin, önde gelen kelime terkipleri arasından seçip, soyutlar. Seçtiği bu zihinsel forumları, imge dünyasında bir kalıp ya da tezgah haline getirir.

Daha sonrada irap ve beyan disiplinleri bakımından Araplara göre sahih kabul edilen kelime terkiplerini seçer. Yapıcı ustasının [duvarı]örmesi ya da dokumacının tezgah üzerinde dokuma yapması gibi, zihin de söz konusu kelime terkiplerini, imgeler dünyasında [zihinsel formlardan]oluşturulan tezgahta dokur ve üretir. Bu durum, terkipler sözün maksadını ifade edecek düzeye gelinceye ve söz dil melekesi bakımından doğru bir şekil alıncaya kadar devam eder."53

Açıkça görülmektedir ki İbn Haldun üslûp hakkında gerek Doğuda yazılanlara dair gerekse el-Kartâcennî'nin bu çerçevede yazdıklarına dair net bir fikre sahiptir. Hatta onun sözlerini ve örneklerini birebir naklettiği bile söylenebilir. ${ }^{54}$

Tunuslu düşünür, kanaatimizce, üslûbun tanımından öte, zihindeki oluşum şekline ve sürecine temas etmiş, bu sürece ilişkin mekanizmayı o günkü anlayış ve dil imkanları çerçevesinde ortaya koymaya çalışmıştır.

Üslûp, İbn Haldun'a göre zihinsel bir formdur. Bu formun oluşumu, ona göre, edîbin söz dizim (nahiv), biçim bilim (sarf) ve belagat kurallarının resmettiği vad' konusunda sahip olduğu dil birikiminden yardım istemesiyle bağlantılıdır. Bu yaklaşım, dil sisteminin bütünlüğüne vurgu yapmaktadır. Bilindiği gibi, biçim bilim (sarf) dil birimlerinin (kelime ve

52 Tabâne, Bedevî, el-Beyânü'l-Arabî, Dâru'l-menâra, Cedde 1988, s. 315.

53 İbn Haldun, Abdurrahman b. Muhammed, Mukaddimetü Íbn Haldun, Tahk. Ali Abdülvâhid Vâfi, Nahdatü Misr, Kahire 2004, III. 1159.

54 Abdulmuttalib, el-Belâga ve'l-üslûbiyye, s. 33, 34. 
harf) iç yapısını araştırır; söz dizim (nahiv) bu birimlerin farklı cümlelerde birbirleriyle olan münasebetlerini; belagat ise, terkiplere ait özellik olan anlamın tam olarak ifade edilmesini araştırır. Bu ilimlerden her birisi, anlatım sürecinde bir diğerini destekler ve birbirleriyle sıkı bir iletișim içine girer. Zira kelimenin iç yapısı, önce içinde bulunduğu cümle içindeki kelimelerle olan ilişkisine, daha sonra da bütün bir parça içindeki kelimelerle olan ilișkisine etki eder. ${ }^{55}$

İbn Haldun'daki bu tasavvura göre üslûp, varsayıma dayalı bir durumdur. İbn Haldun, üslûpla dil kudretini irtibatlandırmıştır. Dil kudreti derken, belirli bir toplumun her bir ferdinde oluşan, ona anlatmak istediği şeyleri yeni cümlelerle ifade etme imkanı sunan gücü kast ediyoruz. ${ }^{56}$

Üslûbun İbn Haldun'da, toplumsal bir olgu şekil aldığı da gözden kaçmamaktadır. Öyle ki bu olgunun ortaya çıktığı toplumdaki bireylere ait söz örneklerinin incelenmesi durumunda, söze ilişkin ideal bir şeklin tasavvuruna yardımcı olan, müşterek etkenlere ulaşılması mümkündür. $\mathrm{Bu}$ bağlamda toplumun bireylerinin aralarında anlaşabilmek için bu ideal şeklin dil ve davranış kuralları içinde kalmaya çalıştıkları da unutulmamalıdır. ${ }^{57}$

Her asırda belagat, edebiyat özellikle de Kuran edebiyatı konusunda ön plana çıkmış alimlerin eserlerinde, üslûp kelimesini kullanımlarından hareketle, 'üslûp' kelimesine yükledikleri anlamı kavramaya ve ne anladıklarını ortaya koymaya çalıştık. Kelimenin vuzuh bakımından İslam Kültüründeki kullanımı, Batı'da olduğundan çok farklı değildir. Klasik metinlerde kelime, çoğu zaman 'esâlîb' şeklinde çoğul formuyla kullanılmıștır. Kelime kullanıldığı bağlamlarda sözlük anlamı olan "çeşitli söz sanatları" ${ }^{\prime \prime 8}$ anlamına gelebileceği gibi, istılâhi bir anlam yüklenmeye de açıktır. Kelimenin belagat kitaplarında bir konu olarak müstakil olarak ele alınmaması, öte yandan zaman zaman yukarıda işaret ettiğimiz gibi, sözlük anlamını aşacak ve günümüzdeki şekliyle örtüşecek kullanımlara sahip olması, anlam alanını gerçek boyutlarıyla ölçmemize mani olmuştur. Cürcânî ve İbn Haldun'un tanım olarak ortaya koyduğu açılamaların tanım olarak kabul edilebilecek düzeyde izahlar olduğunda kuşku yoktur. Onun dışındaki algı ve kullanımlara bakılacak olursa, üslûp anlamının ne

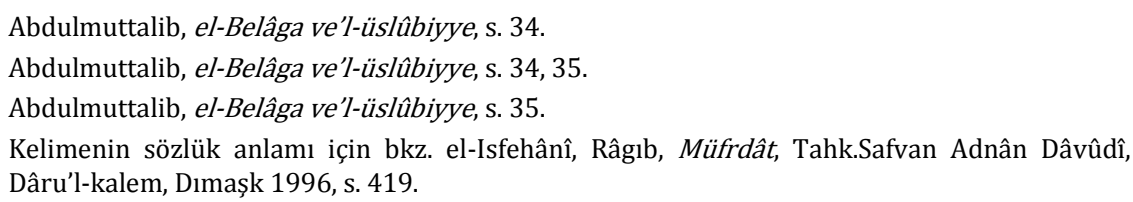


olduğunu çözmeye çalışmaksızın, zevkine varabilecek bir şey, bir tür tabiattan gelen çiçek kokusu olarak görüldügünü söyleyebiliriz.

\section{Modern Zamanlar}

Üslûp konusunun, özellikle dünya edebiyatında tenkit ve retorik konuları arasında önemli bir yer işgal etmesinin ardından, önemli ölçüde günümüz araştırmacıları ve eleștirmenlerinin ilgisine mahzar olmuştur. Öyle ki üslûp olgusu, diğer retorik ve belagat olgularından peyderpey uzaklaşıp müstakil hale gelmiş ve nihayet irfan alanından pek çok araştırmacının ilgisini çeken, dil ve tenkit konularıyla ilgili alt dalları olan müstakil bir konu haline gelmiştir. Üslûp olgusunun önemine ilişkin ilk işaretler, yaklaşık olarak 19.yy.ın sonlarından itibaren ortaya çımmaya, kendisini göstermeye başlamıştır.

Burada üslûp konusuna dair ortaya konulan tüm çalışmaları değerlendirmek durumunda olmadığımız gibi, tüm görüş ve yaklaşımları ele almak durumunda da değiliz. Biz, sadece -çalışmamızın hacmiyle mütenasip olacak şekilde- kavramın netlik kazanmasına katkıda bulunan, ön plana çıkmış tanımlara yer vereceğiz.

Buradaki amacımızın öncelikle, aynı dönemde ortaya çıkan Batı'daki üslûp tanımlarıyla bir simetri kurmak, ikinci olarak ise, "Klasik Dönem" başlığı altında işlemiş olduğumuz bölümde, geleneğe dair tespit ettiğimiz ana damarın, modern zamanlarda nereye kadar devam ettiğini göstermek ve böylece gelenek içinde bir kopuş yaşamadan bir tanıma ulaşmak olduğunu söyleyebiliriz.

800'lü yılların son çeyreğinde Huseyn el-Marsafî (ö.1880) 1875'te yayınlanan "el-Vesîletu'l-Edebiyye" adlı eserinde şiir sanatından bahsederken, üslûp konusuna da yer verir ve büyük ölçüde İbn Haldun'un görüşlerini benimser. Örneğin her ikisi de, her dilin kendine özgü hükümleri olduğu ve bir dilin diğerinden istifade edebileceği görüşündedir. Ayrıca üslûbun elde edilebilmesi için, tek başına dil melekesine sahip olmanın yetmeyeceğini; ibarede hassasiyete ve Araplara özgü üslûpların nasıl kullanıldığının dikkate alınması noktasında gayrete ihtiyaç olduğunu düşünürler. ${ }^{59}$

Şu kadar var ki, Marsafî İbn Haldun'un öne sürdüğü, şiir ya da nesre özgü tarz olarak kabul edebileceğimiz, belli bir üslûbun varlı̆̆ını reddeder. Çünkü ona göre bu geniş bir kısıtlamadır. En muhteşem şairler bile, bizzat

59 Bkz. el-Marsafî, Huseyn b. Ahmed, el-Vesiletü'l-edebiyye li'l-ulûmi'l-Arabiyye, Matbuatu'lmedârisi'l-melikiyye, Kahire 1292, II. 465-503; Abdulmuttalib, el-Belaga ve'l-üslûbiyye, s. 82. 
bir tarz üzerinde ittifak etmiş değildir. Her biri kendisine farklı tarzlar belirlemiștir. Ortada benimsenmesi gereken belirli bir yol yoktur. Sadece dil kullanıcısının kullanmış olduğu terkiplerin, ilmî kuralların belirlediği şekliyle Araplara özgü terkiplerle örtüşmesi söz konusudur. Öyle anlaşllıyor ki Marsafî, bu aşamada, Arapça Dil kurallarına göre sıhhatli olmayı kast etmektedir. Estetik ve ibda'ın ortaya çıktığı ikinci aşamada ise, Arapların kullanmış olduğu tarza uymak zorunlu değildir. Hatta bazılarını kullanmamak bile gerekir. Arapların kullandıkları tarza, ancak sözün söylem amacına uygun olduğu zaman, uyulur. ${ }^{60}$

Üslûp Marsafî̀e göre, birinci derecede ibda' sahibiyle irtibatlıdır. Bunun için ibda' sahibinin bazı özelliklere hâiz olması gerekmektedir: İnşâ kabiliyeti, güçlü bir hafıza, keskin bir zeka. ${ }^{61}$

Marsafî’nin, bireye ait dille ve dilsel davranışla yakından alakası olduğunu varsayarak, yazara ait psikolojik ve fizyolojik oluşum özellikleriyle, yani mizaçla yazarın eserinde kullandığı üslûp arasında bağlantı kurmaya çalışması oldukça ilginçtir.62

Üslûp, aynen İbn Haldun'da olduğu gibi, Marsafî'de de bir melekeye dayanır. Bu meleke mevcut edebî mirası okumak suretiyle hasıl olur. Üslûp, mevcut edebî mirasa sahip olmanın yanı sıra, yazarın özel edebî zevkiyle de alakalıdır. Edebî zevkin, daha doğrusu genel olarak estetik duygusunun nasıl oluştuğuna gelince; eşya arasında bir orantı vardır. Bu orantı oluştuğu zaman, insanların güzelliğini algılama noktasında tabiatları ve eğitimleri bakımından farklı düzeyde oldukları bir şekil ortaya çıkar. Eşyanın oranıyla alakalı olan bu algı, bizim neyi güzel neyi çirkin bulacağımızı belirler. Bu alglya zevk denilmektedir. Zevk, üslûbun hedeflenen amaca uygunluğu bakımından incelenmesiyle gelişen, nitelik kazanan tabî bir şeydir. ${ }^{63}$

Marsafî, üslûpla edebî eserin içermiş olduğu amaç arasında da bir bağlantı kurar. İtap amacıyla yazılmış bir metnin üslûbu, gazelle bir olmayacaktır. Aynı şekilde üslûpta hedef kitlenin duygu ve hissiyatını da dikkate almak gerekmektedir. 64

Üslûbun tabiatı, mahiyeti ve üslûbu oluşturan unsurlar konusuna gelince; yazarın zihninde bu hususlar seyyal ve karmaşık bir vaziyet arz etmektedir. Muhtemelen bu durum yazarın bir yönüyle kadim belagat çalışmalarından etkilenmesi, diğer yönüyle de dil, tenkit ve edebiyat

Abdulmuttalib, el-Belaga ve'l-üslûbiyye, s. 84.

el-Marsafî, el-Vesiletü'l-edebiyye, s. 472.

el-Marsafî, el-Vesiletü'l-edebiyye, s. 472.

Abdulmuttalib, el-Belaga ve'l-üslûbiyye, s. 84.

el-Marsafî, el-Vesiletül-edebiyye, s. 473. Krș. Abdulmuttalib, el-Belaga ve'I-üslûbiyye, s. 85. 
konularında Batı'da yapılmış modern çalışmalardan yararlanmak istemesinin sonucudur. ${ }^{65}$

Yaşadığı dönemde geleneğin önemli temsilcilerinden kabul edilen ve edebî konularda Tâhâ Huseyn ile girdiği sert polemiklerle ${ }^{66}$ tanınan Mustafa Sâdık er-Râfiî (d.1870-ö.1937), üslûp konusundaki görüşlerinde de geleneğin muğlak, belirsiz çizgisinden çok fazla ayrılmamıștır. Üslûp konusuna, bilhassa Kuran üslûbu konusuna temas ettiği I'âzü'I-Kuran adlı eserinde, Cürcânî'den etkilendiği için olsa gerek, sık sık ona ait kavramlara yer verir. Kelimenin bulunduğu bağlam içinde kazandığı yan anlama, 'terkibin ruhu' adını verir. ${ }^{67}$ Beliğ bir söz diziminin üç sesi içermesi gerektiğini düşünür; ruhun sesi, aklın sesi ve duygunun sesi.68

Ona göre, edîpler arasındaki farklılıklar bir yönüyle yaşadıkları dönemle alakalı iken, bir başka yönden insan mizacıyla alakalıdır. Esasen, üslûp farklılığının temelinde de bu vardır. Böylece er-Râfiî üslûbu sözün mizacı olduğunu, sözün ise sahibinin düşünce şeklinden başka bir şey olmadığını ortaya koyar.69 Üslûp yazar ilişkisi konusundaki bu yaklaşımı, Buffon'un meşhur sözünü hatırlatmaktadır: Üslûb-i beyân ayniyle insandır. $\mathrm{Bu}$ görüşleriyle, el-Marsafí'nin el-Vesiletü'l-Edebiyye adlı eserinde temas ettiği konulardan istifade ettiği izlenimini vermektedir. ${ }^{70}$ er-Râfiî Abdülhamid, İbnü'l-Mukaffa gibi seçkin bir üslûba sahip oldukları halde, kimi zaman başarısız olan edîplerin başarısızlık sebeplerini, mizaçlarına uygun üslûp seçmemeleriyle açıklar. ${ }^{71}$

er-Râfiî̀nin sergilediği yaklaşımdan ve yaptığı izahlardan net, ele avuca gelir bir üslûp tanımına ulaşmak hemen hemen imkansız gibidir.

Ahmed Hasen Zeyyât (d.1886-ö.1968), Klasik Belagata dair birikim sahibi, öte yandan Fransız Edebiyatına dair okumaları olan birisi olarak, "Difâ' ani'l-Belaga" adlı kitabında üslûp konusuna yer verir. Eskiye tutunmakla yeniyi kabul etmek arasında bir duruş sergiler. Ne Batı Edebiyatı karşısında okudukları karşısında içine kapanmış ne de Klasik Belagat mirasına dair içselleştirdiklerini bir tarafa itmiştir. Ona göre

65 Bkz. el-Ma'tûk, “Mefûmu'l-üslûb”, s. 12.

66 İtâb üslûbu çerçevesinde her dönemin kendisine has bir edebî zevki ve üslûbu olduğu konusunda Tâhâ Huseyn ile girmiş oldukları polemik için bkz. Huseyn, Tâhâ, Hadîsü'l-erbiâ, Dâru'l-meârif, Kahire ty., III. 5-30.

67 er-Râfiî, Mustafa Sâdık, I'câzü'l-Kuran ve'l-belagatü'n-nebeviyye, el-Muktataf, Kahire 1928, s. 325.

68 er-Râfiî, I'câzü'l-Kuran, s. 290, 291.

69 er-Râfiî, I'câzü'l-Kuran, s. 267.

70 Abdulmuttalib, el-Belaga ve'l-üslûbiyye, s. 90.

71 er-Râfiî, I'́câzü'l-Kuran, s. 268. 
Batı'dan gelen fikri tufan karşısında, tutunabileceğimiz pek çok sanat değerimiz bulunmaktadır. ${ }^{72}$

Görünen o ki Zeyyât'ın kadim mirastan istifadesi el-Askerî ve Cürcânî ile sınırlı kalmıştır. Çünkü bu iki isimden sonra belagat duraklama dönemine girmiştir. Üslûp konusunda ne Cürcânî̀nin söyledikleri üzerine bir tuğla konulmuş, ne de İbn Haldun'un yaklaşımı devam ettirilmiştir. ${ }^{73}$

Zeyyât incelemesini Batılıların üslûp anlayışı ile Klasik Belagat arasında mukayeseli bir şekilde götürmeye çalışmıştır. Bu noktadan hareketle üslûbu "yazar ya da șairin kelimelerin seçimi ve diziminde takip ettiği özel yoldur" şeklinde tarif etmiştir.74 Zeyyât böylece Cürcânî'nin nazım, şair/yazarın terkip gücü etrafında söylediklerinden ilham alır. Aynı zamanda üslûpla sanatçının ele aldığı sanat sonra üslûpla seçtiği konu arasında bağlantı kurar. Yukarıda vermiş olduğumuz tanım kendisini tatmin etmemiş olacak ki ikinci bir tanım yapar: Üslûp düşünceyi yaratma ve onu uygun lafız formları içerisinde ortaya koyma yöntemidir ${ }^{75}$ Üslûp sürekli bir yaratmadır: Anlam aracılığı ile lafızları, lafızlar vasıtasıyla anlamı yaratmadır. Üslûp, sanatçının çeşitli unsurlardan meydana getirdiği sanatsal bir sentezdir. Sanatçı bu unsurları, zihninden, ruhundan ve zevkinden derler. Bu unsurlar, düşünce, şekil, duygular; lafız birliktelikleri ve muhtelif güzelliklerdir. Zeyyât'ın genel tarzı, Romantizme yakın olduğunu göstermektedir. Çünkü edebiyat - özellikle şiir- romantiklere göre hayat ve tabiatı taklit değildir. Tam aksine sürekli bir yaratmadır. Yaratmanın vasıtası ise, dağınık unsurları bir araya getiren ya da orijinal bir şekilde yaratan bir hayal gücüdür. ${ }^{76}$

Zeyyât aralarındaki karşılıklı etkileşimi dikkate alarak milletlerle konuştukları dil arasında ilgi kurmaya çalışır. Bir yerde dillerin millî karakteri üzerinde durur. Bu konuda dilleri irki özelliklere göre tasnif etmiş olan Friedrich Miiller'in çağrısından etkilenmişe benzemektedir. ${ }^{77}$

Zeyyât üslûba dair araştırması sırasında biçim-içerik, ya da lafız-anlam meselesini gündeme getirir; bu alandaki kadim tenkit yaklaşımlarına temas eder. Bu yaklaşımları ikiye ayırır: Lafız-anlam ilişkisini beden-elbise ilişkisi şeklinde gören yaklaşım ki buna göre her birinin diğerinden müstakil bir

72 Hasen, Zeyyât, Difa' ani'l-belaga, Âlemü'l-kütüb, Kahire 1967, s. 68; Abdulmuttalib, el-Belâga ve'l-üslûbiyye, s. 98.

73 Abdulmuttalib, el-Belâga ve'l-üslûbiyye, s. 98.

74 Zeyyât, Difa' ani'l-belaga, s. 70.

Zeyyât, Difa' ani'l-belaga, s. 76.

Abdulmuttalib, el-Belâga ve'l-üslûbiyye, s. 99.

Abdulmuttalib, el-Belâga ve'l-üslûbiyye, s. 99, 100. 
varlığı vardır. ${ }^{78}$ Diğer yaklaşım ise, bu alakayı beden-ruh ilişkisi olarak gören yaklaşımdır. Bu yaklaşıma göre, bu iki unsurdan birisi olmazsa diğeri de olmaz. Zeyyât bu ikinci yaklaşımı benimser. Ona göre üslûp belagat melekesinin ruhî hendesesidir.79 $\mathrm{Bu}$ meseledeki yaklaşımıyla Cürcânî'nin çizmiş olduğu çerçevenin dışına çıkmamıştır: "Formda yapacağımız bir değişiklik düşüncede değișikliği; düşüncede yapacağımız bir değișiklik de

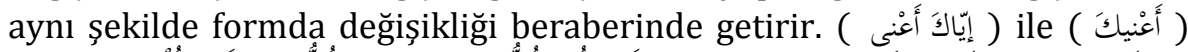

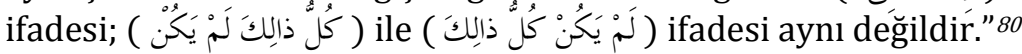

Zeyyât anlam-lafız ilişkisini ruh-beden ilişkisi olarak gören yaklaşımı benimsemesinin ardından formalistleri destekleyen bir tavır içine girer. Zira dış yapıda yapılacak bir iyileștirme düşüncede iyileștirmeyi gerektirir ama tersi böyle değildir. Anlaşılan o ki Zeyyât'ın Romantizm Akımını benimsemesi sonra, Realizm hareketinin kurucusu Flaubert'ten ${ }^{81}$ etkilenerek Realizm Hareketinin prensiplerine muttali olması, onu bu noktaya sevk etmiștir. ${ }^{82}$

Abdülmuttalib'in belirttiğine göre, Flaubert estetik değeri her türlü değerin üstüne koymuş ve estetiği yaratmanın sanatçının yegâne görevi olduğunu düşünmüştür. Ona göre estetik, düşünce, şekil ve üslûbun karıșımı bir șeydir. Zeyyât'ın anladığı gibi, formla sınırlı bir șey değildir. ${ }^{83}$

Zeyyât'a göre belagatın gerçekleşebilmesi için üslûpta üç niteliğin bulunması gerekir: Asalet, îcaz ve uyum. ${ }^{84}$

1. Asalet: Düşünce, șekil ve ruh bakımından yazarın kişiliğini temsil eder. İki esasa dayanır: Lafzın hususiyeti ve ibarenin orijinalliği. Lafzın hususiyeti derken, Cürcânî'nin kast ettiği, kelimenin cümle içinde aldığ konumu kast eder. Kelimeler sözlükte oldukları sürece ölüdürler, onlara hayat veren yazarın cümle içindeki kullanımıdır. ${ }^{85}$ İbarenin orijinalliğinden

78 Abdülmuttalib bildiğimiz kadarıyla, Edebiyat Tarihinde ikinci türden, lafızla anlamı bir birinden bağımsız iki varlık kabul eden bir yaklaşım olmadığını belirtir. Abdulmuttalib, elBelâga ve'l-üslûbiyye, s. 101.

79 Zeyyât, Difa'ani'l-belaga, s. 74.

80 Zeyyât, Difa'ani'l-belaga, s. 74.

81 Flaubert, bir kelimedeki bir sesi ve bir sayfada aynı kelimeyi tekrar etmemek gibi sadece kendisine mahsus bir prensibi benimsemiștir. Kulağı, kelimelerin formüle edilmesinde en büyük hakemdi, kulağı sadece insicamı güzel kelimelere, eşit kelime öbeklerine ve birbirin dengeleyen paragraflara izin verir. Flaubert Romantizm akımını benimsemesine ve şiirlerini okumaya hevesli olmasına rağmen, Realizm'i ideal akım olarak kabul etmiștir. Bkz. Abdulmuttalib, el-Belâga ve'l-üslûbiyye, s. 102.

82 Abdulmuttalib, el-Belâga ve'l-üslûbiyye, s. 102.

83 Abdulmuttalib, el-Belâga ve'l-üslûbiyye, s. 102.

84 Zeyyât, Difa'ani'l-belaga, s. 95.

85 Zeyyât, Difa'ani'l-belaga, s. 96, 97. 
maksat ise, olayın anlatımında, düşüncenin tasavvurunda ve konunun düzenlenmesindeki orijinalitedir. 86

2. Îcaz: Klasik belagatçılarda olduğu gibi, Zeyyât'ta da belagatın tanımıdır. Zeyyât, az sözle çok mana ifade etmek demek olan vecizliği belagatın aslı, aynı şekilde Sami Dillerle Hint-Avrupa dilleri arasındaki temel ayrım noktası olarak kabul etmiştir. ${ }^{87}$ Îcaz bir yerde konuşmacının dinleyici ve okurun vaktine saygısıdır. Bu yüzden yazarın yazdı̆̆ı șeye özen göstermesi gereklidir. Dolayısıyla yazar yazısını gereksiz sözlerden temizler, eş anlamlı kelimelerden kurtarır. Sonra metne tekrar döner îcaz tafsil dengesini gözden geçirir. Çünkü her biri yerine göre güzeldir. Tafsil de lafzı anlamına göre belirlendiği takdirde îcaz olarak kabul edilebilir. ${ }^{88}$

3. Uyum: Üslûpta estetiksel unsurdur. İnsan tabiatı icabı kendisini kuşatan her güzelliğe tutkundur; kullandığı ev, yemek, ev eşyası ve tabiattaki tüm güzellikler. Bu tutkunun üslûba, üslûbun içindeki kelimelerin tatlılığına, paragraflar arasındaki simetriye, cümleler arasındaki denge ve ses uyumuna uzanması kaçınılmazdı. ${ }^{89}$

Zeyyât, çalışmasında önce üslûpla üslûp sahibi arasındaki ilişkiye, sonra üslûpla muhatap arasındaki ilişkiye daha sonra da üslûpla konu arasındaki ilişkiye işaret etmiştir. Üslûplar, ona göre zihin, kültür, tür, amaç, hâl ve konuşulan kişiye göre farklılık arz eder.

XX. yy. ın ikinci çeyreğinde Ahmed Şâyib'in "Üslûb" adlı eseri, üslûp inceleme ve araştırmasına dair o güne kadar gerçekleştirilmiş en kayda değer çabalardan birisi ve belki de en önemlisidir. Eser, Batı tenkit kültürüne dair yapılmış okumaların ve klasik Arap belagatı ve tenkit geleneği ile uzun süren bir beraberliğin semeresidir. Üslûp anlayışındaki hareket noktası, Marsafînin hareket noktası yani İbn Haldun'un üslûba dair geliştirdiği tanım ve sınırlardır.

Yazara göre, üslûp söz sanatıdır; hikaye olur, senaryo olur, teşbih, mecaz, kinaye olur; rapor, hikmet ve mesel olur..$^{90}$ Şâyib üslûbu edebî türle ve edebi sanatlarla ilişkilendirmiştir. İlginç olanı ise, edebî anlamda hikaye ile mecaz ya da kinayenin eşit tutmuş olmasıdır. Hal bu ki, mecaz ve kinaye gibi sanatların edebî türlerde kullanılan anlatım araçlarından başka bir şey olmadığı malumdur. ${ }^{91}$

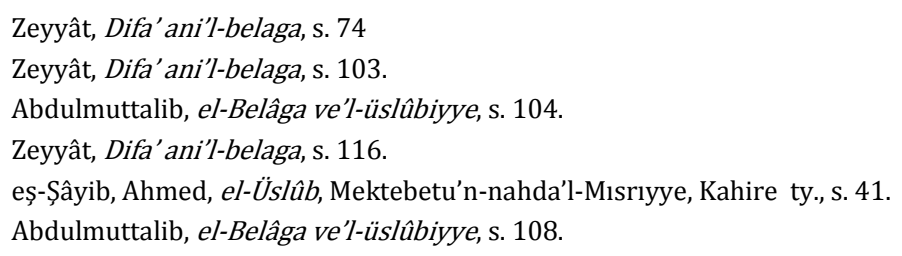


"Üslûbun öteden beri anlamında özel şeklî bir yön mülahaza edilir ki, bu şeklî yön; edîbin içindekileri tasvir etmek yahut onları dil unsurları aracılı̆̆ ile başkalarına nakletmek üzere tuttuğu anlatım yoludur. Bu üslûbun günümüze kadar devam ede gelen tanımıdır. Sonuç olarak üslûp yazım şekli, inşâ şekli veya açıklama yapmak ve (muhatapta) etki oluşturmak amacıyla, anlamı ifade etmek üzere, kelimeler üzerinde yapılan seçim ve dizim șeklidir. ${ }^{\prime 2}$

Şâyib, üslûp kavramını dilsel terkip üzerinde yoğunlaştırmaya çalışır, bunu yaparken ise iki noktayla ilişkilendirir:

1. Yazarın benimsediği özel tarza göre kelimelerin dizimi noktasında seçim yapabilme gücü.

2. Yazarın muhatabı üzerinde oluşturmayı amaçladığı etki faktörü.

Zaman zaman, üslûptan kelime, cümle ve ibareden oluşan lafzî unsuru anlayan kimselerle diyalektiğe girer ve lafzî unsurun yazarın kafasında, iç dünyasında -adına manevî üslûp dediği- başka bir sistemle alakalı olduğunu belirtir.93 Manevî üslûpla muhtemelen, üslûbun zihinsel aşamasını, kelimelere dökülmeden önceki safhasını kast etmektedir. Nitekim şöyle der: "Tasvirde, (metni oluşturan) terkip ve ibare düzeyindeki unsurların tasvir edilen olguya uygun bir tınıya sahip olması gerekir. Öyle ki lafzî üslûp manevî/zihinsel üslûbu yansıtsın ve lafizla anlam arasında bir insicam sağlansin..."94

Şâyib, lafza ilişkin yapının, çok güçlü ve ayrılmaz bir şekilde, anlama ilişkin zihinsel formlarla irtibatlı olduğunu ortaya koyar. Çünkü Şâyib'in bakış açısına göre; "lafza iliş̧kin formun tek başına hayatta kalması mümkün değildir. Lafza ilişskin formun dışa bakan düzeni, varlığını yazar ya da konuşmacının iç dünyasında dizimini gerçekleştirdiği anlama iliş̧kin düzene borçludur."Bunun anlamı şudur: "Üslûp aslında, lafza bürünmeden önce bir düzene girmiş anlamlar bütünüdür." ${ }^{\prime 95}$

Edebiyattaki üslûpla diğer güzel sanatlardaki üslûbu mukayese eder ve üslûbun ifade tarzı olduğunu vurgular. Çünkü, diğer sanat dallarına ait ifade tarzları da vardır; sanatçıların bildiği ve araçlarını nağmelerden, renklerden ve taşlardan elde ettikleri ifade tarzlarıdır bunlar... Aynı şekilde ilim adamlarının da araştırmalarında kullandıkları sembol, terim ve metotları vardır. Buna göre üslûp, düşünce ve tasvir şeklidir. Bu tanım, görüldüğü

eş-Şâyib, el-Üslûb, s. 44. Krş. Abdulmuttalib, el-Belâga ve'l-üslûbiyye, s. 108.

Abdulmuttalib, el-Belâga ve'I-üslûbiyye, s. 107, 108.

eş-Şâyib, el-Üslûb, s.106.

eş-Şayib, el-Üslûb, s. 40. 
üzere, üslûbun unsurlarını ve diğer sanat dallarındaki üslûp tanımlarını ele almaktadır. ${ }^{96}$

Yazar, ibda sahibinin sübjektifliğini merkez alan bu tanımlamayı içine sindirememiş olacak ki -muhtemelen bilinçsizce- dilsel metni merkeze alan bir tanımlamayı tercih etmiştir. Böylece Şâyib, bir taraftan edebiyata romantik bakışın yaşamış olduğu sarsıntıyı dillendirmekte, diğer taraftan da inşâ sahibinin hayatından bağımsız, bir metin tasavvurunu öngören, metni bağımsız bir olgu olarak ele alan başka bir bakış açısının gerekliliğini ifade etmektedir. Edebiyata yönelik bu yaklaşım, Birinci Dünya Savaşını müteakiben Avrupa ve A.B.D.'de ortaya çıkmış ve kırklı yıllardan itibaren etkili olmaya başlamıştır.

Son olarak günümüz yazarlarından üslûp konusunu müstakil bir makalede ele alan bir isme Ahmed Muhammed el-Ma'tûk'un konuyla ilgili görüşlerine yer vermek istiyoruz. 'Mefhûmu'l-Üslûp' isimli makalesinde, üslûp kavramının günümüzde bile kapalılığını korumaya devam ettiğini belirten yazar, kelimenin Batı ve İslam dünyasındaki serüvenine kısaca temas eder. Yazarın bilhassa kavramın İslam Dünyasındaki algılanış şekline dair yapmış olduğu bazı yorumlar, esefle belirtelim ki referansları açısından doğrulanmaktan ve altı doldurulmaktan uzak abartılı yorumlardır. ${ }^{97}$

Makalesi çerçevesinde kavramın kısa tarihçesine temas eden yazar, kavramın Arapça'da ki sözlük anlamı olan, 'yol' kelimesinden hareketle semantik bir analizde bulunmaya çalışır: "Üslûbun, pek çok Arapça sözlükte yaygın olan sözlük anlamı "uzanan yol" ya da "gidilen yol" manasını alıp tahlil ettiğimiz zaman, ifade yapısıyla olan irtibatı yönüyle üslûp gerçeğini izah edebiliriz. "Yol" denilince, yolun oluşumunda dikkate alınan çeşitli aşama ve unsurlar söz konusudur.

1. İki noktayı, muayyen iki hedefi birbirine bağlama veya birleştirme düşüncesi.

2. Bu birleştirmenin şekil ve yapısının zihinde resmedilmesi.

3. Bu işi gerçekleştirmek için uygun olan malzemenin seçimi.

4. Uygun malzemenin, uygun yerlere konulması."98

Yazar kavramla kavramın sözlük anlamı arasındaki ilişkiden hareketle bir yol anaforu oluşturur ve bu çerçevede üslûbun zihinde oluşum sürecine yer verir: "Kendisine yol yapım görevi verilen bir mühendis düşünelim, mühendisin ilk yapacağı şey bunu zihninde tasarlamak olacaktır. Daha sonra, kağıt üzerine aktarılmış bu tasarı halindeki projesini tabiata

\footnotetext{
Abdulmuttalib, el-Belâga ve'l-üslûbiyye, s. 109.

Bkz. el-Ma'tûk, "Mefûmu'l-üslûb”, s. 7-11.

el-Ma'tûk, "Mefûmu'l-üslûb”, s. 15.
} 
uygulamak için zemin etüdü yapar ve uygun olan malzemeyi seçer. Mesela, yol geçecek yer aşırı sıcak bir yerse, sıcağa mukavemetli malzeme seçer. Yolun geçeceği yer sslak ve nemli bir zeminse malzemeyi ona göre seçer. Nitekim yapılmış bir yol hakkında değerlendirme yaparken de yukarıdaki unsurları dikkate alarak bir değerlendirme yapar:

1. Bu yolun birleștirdiği iki nokta, bu iki noktanın önemi, temel bir düşünce olarak bu bağlantının gerçekleștirilmesi.

2. Yolun durumu ve şekli: Düz, uzun, kısa, geniş, kıvrımlı, virajlı. Bir başka deyişle, yol hedefe kolay bir şekilde mi varır yoksa zor ve kıvrımlı bir şekilde mi?

3. Yolun yapımında kullanılan malzeme: Taş, kaya, asfalt, döşeme. Başka bir ifadeyle yol düz ya da değil, topraklı ya da kayalı yoksa yumuşak, çamurdan mı?

4. Son olarak yolun genel manzarası dikkate alınır: İnsana yakın, canll, aydınlık, ağaçlı, güzel bir yol mu yoksa ıssız, karanlık, çorak, tekdüze mi?"99

"Konuştuğumuz veya yazdığımız zaman, düşüncelerimizi ya da tecrübe ve birikimlerimizi başkalarına aktarırız. Başka bir deyişle, zihnimizi başkalarının zihinlerine, duygularımızı başkalarının duygularına ulaştıran yol ya da yollar inşâ ederiz."

"İnsanoğlu müktesebatında olan bilgileri yahut zihnine doğan düşünceleri ve iç dünyasında reaksiyona giren duygularını başkalarına ulaştırmak ister. Bunu yaparken amacımız karşı tarafla iletişim kurmak; onları tecrübelerimize ve duygularımıza ortak etmektir. Kuşkusuz düşünce ve duygularımız gelişi güzel bir şekilde ortaya çıkmazlar. Sağlıklı bir iletişimin gerçekleşmesi için uygun şekil veya tasarımlara bürünmesi gerekecektir. $\mathrm{Bu}$ noktada kendimize, karşı tarafa düşünceyi nakletmeye nasıl başladığımızı? Nasıl aşamalı bir süreç takip ettiğimizi? Düşünceyi oluşturan halkaları birbirine nasıl eklediğimizi? Nasıl sonlandırdığımızı sormamiz gerekir."

"Düşüncenin şekillenmesi ya da zihnimizdeki hendesesi birkaç saniye içinde gerçekleşir. Parçalarının birbiriyle kaynaşması, halkalarının zincir oluşturması peşi sıra birbirini takip eder. Çoğu zaman bilgilerin hafızadan intikali veya duygularımıza ve hayal dünyamıza ilişkin duygusal durumumuzun bedene bürünmesi hissedemeyeceğimiz bir hızla gerçekleşir. Şu kadar var ki, bu tasavvur ve tasvir veya zihinsel tecessüm, ikinci merhale olarak meydana gelmelidir. Bu aşamada kendisi aracılığıyla fikirlerimizi naklettiğimiz maddeye yani dile, dilin terkiplerine ve kelime

99 el-Ma’tûk, “Mefûmu'l-üslûb”, s. 15. 
haznesine yöneliriz ki, böylece bu dil malzemesi içerisinden, ulaştırmak istediğimiz düşünce ve duygulara uygun olanları kendileri için belirlemiş olduğumuz zihinsel formlarla birlikte seçebilelim. Bunu yaparken, hedef kitlenin içinde bulunduğu durum, zihin gücü, sözün veya konunun söyleniş sebebi neyi gerektiriyorsa onu da dikkate alırız."

"Düşünce, malumat ve tecrübelerimizi aktarmak için seçmiş olduğumuz yapmış olduğumuz seçim işlemi bizim kavrayamayacağımız bir hızla gerçekleşir. Seçimi müteakiben, seçilen unsurlar gramer kuralları ve dilin itibari durumları dikkate alınarak derhal birbirleriyle birleştirme yoluna gidilir. Böylece ifadenin oluşum süreci başka bir ifadeyle yol yapım işlemi tamamlanmış olur. Bu esasa göre biz, bu yol yapımında dört aşamadan geçmiş oluruz. Bunlar:

1. Başkalarına ulaştırmak amacıyla, herhangi bir düşüncenin doğması veya zihnimizdeki düşünceler arasından seçimi. Kimi zaman da bu iç dünyamızda içsel bir tecrübenin reaksiyona geçmesi şeklinde olabilir. Hedef birim ve kaynak birimden her birinin zihni, burada aralarında bağlantı kurulmak istenen iki hedeftir.

2. Bu düşünce ya da tecrübenin unsurlarının, sahibi tarafından tasavvur edilmesi daha sonra bunların ortaya konması istenilen şekliyle muhayyilede tasvir ve tertibi. Başka bir ifadeyle, düşüncenin içsel olarak hendesesi ve tasarımı ve soyut bir kalıba konması ve belirli bir şekilde zihinden çıkması için hazır hale getirilmesi.

3. Ulaştırmak istediğimiz bilgi ve düşünceye yahut hissettirmek istediğimiz duygu ve tecrübelere uygun kelime ve cümleciklerin seçimi. Başka bir deyişle, hafızamızdaki kelime haznesinden zihinde tasarlanmış ve yapılanmış ya da hayalde canlandırılmış anlama ilişkin kalıp ve terkiplerin seçilmesi.

4. Dil kurallarına uygun bir şekilde seçimi gerçekleşmiş olan kelime ve terkiplerin belirli bir ifade yapısı ya da dizge içine konulması. Böylece, düşünce ya da tecrübe, dilin çerçevesi ya da duygu dünyası içinde bedenleşir ve söylemek istediğimiz sözün formu tamamlanmış olur. Bunun tamamlanmasıyla birlikte, yolun tamamlanmasında olduğu gibi, üslûbun oluşumu da tamamen gerçekleşmiş olur."100

Yazara göre bu, bir konuşmacının hissedemeyeceği kadar hızlı gerçekleşen, birbirini takip eden, iç içe geçmiş dört merhale, bir yerde üslûbun geçmiş olduğu merhaleler ve üslûbun oluşumunda yer alan temel unsurlardır. Söz konusu unsurlar ve aşamalar sebebiyle, üslûp şahıstan

100 el-Ma'tûk, “Mefûmu'l-üslûb”, s. 15, 16. 
şahısa, durumdan duruma, sanattan sanata ve bir konudan diğerine değişen bir olgu olmuștur. ${ }^{101}$

"Hedef birim konuşmamızı dinlediği ve yazdığımızı okuduğu zaman, zihnimizle kendi zihnini; duygularımızla kendi duygularını birleştirdiğimize karar verir ve bu süreçte hedef birimin düşüncesinde mezkür tüm unsur ve merhaleler mevcuttur. Hedef birim bunlar aracılığıyla, tıpkı üzerinde yürüdüğü yol hakkında hüküm verdiği gibi, düşünce ve tecrübelerimiz; onların özgünlügü ve önemi hakkında hüküm verir."

"Sonra hedef birim, ortaya koymuş olduğumuz hendesi şekil ya da içinde tecrübelerimizi ibraz ettiğimiz düşünceler, muhkem bir şekilde birbiriyle irtibatlı mı? Parçaları bir biriyle uyumlu mu? Zihinde bir şey canlandırıyor mu? Geniş, kapsamlı ya da etkili mi? Yoksa gevşek dokunmuş, pörsümüş, unsurları uyumsuz, basit, eğreti olup olmadığına karar verir."

"Daha sonra, düşünce ve tecrübeleri kendileri vasıtasıyla gerçekleştirdiğimiz unsur ya da dil kalıplarının özgünlüğü ve değeri - ki bunlar bu özelliklerinden dolayı tercih edilmiştir- konusunda şu açllardan değerlendirmede bulunur: Bu dil unsurları dile getirmek istenilen anlamı aksettiriyor mu, telkinde bulunuyor mu, aktarmak istediğimiz düşüncelere uygun mu, telaffuzu kolay, müzikalitesi yüksek mi yoksa bütün bu niteliklerin tersi mi? Böylece hedef birim, kendisiyle aramızda duygu ve düşünce iletişimi için inşâ etmiş olduğumuz yol hakkında, girmiş olduğu etkileşime, mizacına, sahip olduğu alt yapıya, fikri seviyesi ve bilinç düzeyine göre genel bir yargıda bulunur. Buraya kadar tanım ve tasvirini yaptığımız yol aslında "üslûp"tan başkası değildir."102

Ma'tûk'a göre, üslûbun, üslûp sahibinin dil unsurlarından yapmış olduğu seçimden ibaret sayılması mümkün değildir. Bunlar sadece kaynak birimin başlangıçta, zihninde ürettiği ve belirlediği düşünce ve anlamlar için birer rumuz ya da kalıptırlar. Üslûp bu kelime ve dil birimlerine özel bir form değildir. Genel olarak dil birimleri aklın anlamı, zihinde şekillendirilmesinden ve bağlantılarını zihinde canlandırmasından sonra ifadeye konur. Dil birimleri soyut zihinsel kalıplarla ilişki halindedir. Üslûp, bu kelimelerin içeriği ve bu kelimelerden oluşan terkip ve kalıpların delâlet etmiş olduğu şey de değildir. Bu anlam ve düşünceler, ancak lafzî formlarına konulduktan sonra bize ulaşır. ${ }^{103}$

Üslûp, bir söylemde parçaları iç içe geçmiş, biri diğerinden ayrılması imkansız, herhangi bir birimi hakkında tek başına hüküm verilmesi ya da

\footnotetext{
el-Ma'tûk, “Mefûmu'l-üslûb”, s. 16.

el-Ma'tûk, "Mefûmu'l-üslûb”, s. 16.

03 el-Ma'tûk, "Mefûmu'l-üslûb”, s. 17.
} 
diğer bir ifadeyle, geneli için verilen bir hükmün, üslûbu oluşturan diğer unsurlar için de teker teker geçerli olmadan, haklarında hüküm verilmesi mümkün olmayan bütün bu unsurların, tam bir bütünlük içerisinde bir araya gelmesidir. ${ }^{104}$

Bu tahlilin ışığı altında Ma'tûk üslûbu şöyle tanımlar; anlam ya da düşünce, bu anlamın tasviri ve zihinsel kalıbının içine konulması; kelimeler ve dilsel terkipler ve bunların ifadeye dökülmesi ve söz konusu ifadenin, anlamı bütün unsurlarıyla canlandıracak belirli bir dizge içine konulmasidir. ${ }^{105}$

Herhangi bir şahsın üslûbu demek, "onun üretme ya da seçme tarzı, fikir ya da anlamları tasavvuru, onları tasvir tarzı, parçalarının insicamı ve unsurların zihinde bir araya getirilmesi. Sonra bunların dil kalıpları içerisinde canlandırılma tarzıdır." Açıktır ki, düşünce ya da anlamların dil kalıpları içerisinde canlandırılması, kelime ve terkiplerin ifadeye konmasını ve bunların zihinsel insicama uygun olarak belirli bir dizayn içerisine konulmasını da kapsamaktadır.106

\section{3. Üslûbun Tanımına Doğru}

Şu ana kadar üslûbun hem Batı kültüründeki tanım ve gelişim süreçlerini hem de İslam kültüründeki durumunu ele almaya çalıştık. Üslûp kavramı Batı'da edebî anlamda XVI.ıncı yy.ın sonlarında tanımlanmaya ve bu çerçevede kullanılmaya başlandığı halde, İslam Dünyasında henüz XI.yy.da tanımlanmasının ötesinde, 'Şeyhu'l-Belaga' olarak anılan Abdülkâhir Cürcânî (ö.1078) tarafından 'nazm' ismi altında bir sistem olarak ele alınıp incelenmiştir.

Üslûbun hayat hikayesi İslam kültüründe bir hayli eskiye dayanmasına ve köklü olmasına mukabil, gelişim süreci aynı șekilde devam etmemiştir. Öte yandan Batıdaki gelişim süreci ise bilhassa XVIII.inci ve XIX.uncu yy.larda bir hayli hızlı ve girift olmuştur. Bilhassa XIX.yy.da sistemleştirme ve bilimselleştirme yönüne gidilmiştir. Kuşkusuz üslûp anlayışının gelişip ve tekâmül etmesi, bulunduğu kültürdeki düşünce ve edebiyat faaliyetleri; verilen edebî ürünlerin nitelik ve niceliği ile yakından alakalıdır. Batıdaki bu hızlı ve girift tekâmülün sebebini bu noktada aramak gerekir. İslam

\footnotetext{
104 el-Ma'tûk, "Mefûmu'l-üslûb”, s. 17.

105 el-Ma'tûk, "Mefûmu'l-üslûb”, s. 16.

106 el-Ma'tûk, "Mefûmu'l-üslûb”, s. 16.
} 
Dünyasında ise üslûba dair pek çok hakikat çok erken dönemde (XI.yy.) yakalanmış olmasına rağmen arkası getirilememiştir.

İnșânın dıș mimarisi olan üslûbun önemli olduğu kadar, tanımlanması zor bir konu olduğu gerçeği her iki kültürün, geçmişte ve günümüzde üzerinde ittifak ettiği bir husustur. Üslûp, uygulaması da nazariyesi de incelemesi de zor olan bir konudur. Zira üslûp incelemesi, dille edebiyatın kesiştiği, bir yönüyle normatif diğer yönüyle sübjektif bir alanda, kaynak birim, hedef birim, araç ve amacın ve bunları kuşatan tarihsel şartların fazlasıyla faal olduğu zihinsel ve psikolojik bir sürecin dil düzleminde çözümlenmesi, görünür kılınması faaliyetidir. Nitekim Valéry'ye, Collége de France'daki derslerini neden yayımlamadığı sorulduğunda, "Biçim pahalıya mal olur." demesi bu sebepledir... ${ }^{107}$ Gerçekten üslûp da işçiliğiyle, tanımlanmasıyla ve incelenmesiyle maliyeti oldukça yüksek bir iştir.

Bütün bu zorluklarına rağmen üslûbun zihindeki oluşum sürecinden başlayarak, oluşumundan sonra yazarın iç dünyasına, birikimine ve kişiliğine dair sunmuş olduğu verilere yönelik kimi tespitleri paylaşmaya ve bir tanım denemesinde bulunmaya çalışacağız. Kuşkusuz bu nihâi bir tanım değil, sadece bir tanım çabasıdır.

Bir inşâ ya da konuşma ameliyesinde, zihin ilk aşamada kendine özgü bir şekilde ürettiği anlam ve düşünceleri ifade etmek üzere belirli kelime ve cümlecikler seçer. Daha sonra bu seçim sürecini, bir diğer süreç olan özel bir form ve muayyen bir dizge içine konulması takip eder. Bu özel form ve muayyen dizgenin temel özelliği; yazarın zihniyetini, hissediş şeklini, zevkini, hayal gücünü, mizacını, sosyal konumunu, kültürünü, sahip olduğu inşâ yeteneğini ortaya koymaktır. Bu sayede, konuşmacının şahsiyeti bütün unsurlarıla ortaya çıkar.

Yazarın seçtiği kelimeler aracılığı ile dile olan vukûfiyetinin derinliği ya da sathîliğini, talâkati ya da za'fını, kelime ve terkip birikimini, bu kelime ve terkipleri yerli yerinde kullanma becerisini tanımış oluruz. Bu kelimelerin ifadeye konması ve muayyen bir dizge içine sokulması sayesinde ise yazarın ifade kurgusu, kelimeler ve bu kelimelerin ritmi, armonisi gibi konular hakkında ne tür bir estetik algıya sahip olduğuna dair bilgi sahibi oluruz. Aynı şekilde, yazarın anlam ve çağrışımları tasvir ve canlandırma gücü ile bunlara ilişkin soyut bağlantı kurma gücünü de keşfederiz. ${ }^{108}$

Yakın dönem araştırmacılarından Hockett "Course in Modern Linguistics" adlı eserinde şunu öne sürer: "Yaklaşık olarak aynı bilgiyi

107 Barthes, Roland, Yazının Sıfır Derecesi, Çev.Tahsin Yücel, Metis Yayınları, İstanbul 2006, s. 56.

108 el-Ma'tûk, "Mefûmu'l-üslûb", s.16. 
taşıyan fakat linguistik yapı bakımından farklı olan aynı dildeki iki sözce, üslûp bakımından farklıdır, denilebilir; 'He came too soon' (Cok çabuk geldi) ve 'He arrived prematurely'(Erken geldi) örneklerinde olduğu gibi." ${ }^{109}$ Hockett'in bu tezini doğrulayan benzeri bir örneği Arap Edebiyat tarihinden bir anekdotla teyit etmek istiyoruz.

Asmaî kendisinin şahit olduğu, Arap Dili ve Edebiyatı'nın önde gelen isimleri arasında geçen bir olayı bize şöyle nakleder: "Beşşâr'ın yanındaydım, Ebû Amr İbnü'l-Alâ (ö.771) ile Halefü'l-Ahmer (ö.796) çıka geldiler. Gayet saygılı bir şekilde selam verip, 'Yeni ne var, ey Ebû Muâz?' dediler. Bunun üzerine Beşşâr kendilerine yeni şiirlerini okudu ve onlar da bu şiirleri son derece mütevazı bir şekilde yazdılar. Derken o gün öğle oldu onlarda müsaade alıp gittiler.

Yine böyle bir gün sohbet esnasında Beşşâr'a;

- 'Sel b. Kuteybe için yeni kaside yazmışsın?' dediler. 0 da 'doğrudur' dedi.

- 'Söylendiğine göre oldukça fazla sayıda az bilinen kelimelere (garîb) yer vermişsin ama!' dediler. Bunun üzerine şöyle dedi:

- 'İşittiğim kadarıyla Selm bu tür kelimelere meraklıymış, ben de bilmediği kelimeleri kullanayım istedim' dedi. Bunun üzerine kasideyi kendilerine okumasını istediler. 0 da başlangıç beyti aşağıda yer alan

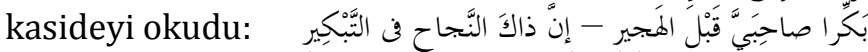

Anlamı: "Öğle sıcağı basmadan érken davranın arkadaşlar! Başarı erken davranmaktadır."Bunun üzerine Halef,

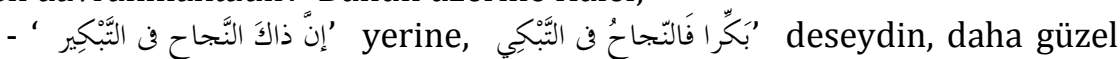
olurdu' dedi.

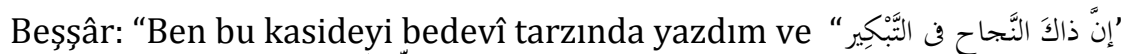

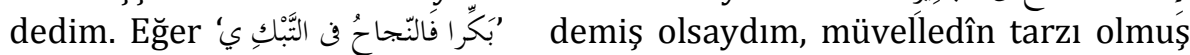
olurdu ki diğerine benzemez, kasideye de uygun düşmezdi" dedi. ${ }^{110}$

Görüldüğü gibi Beşşâr, kelimelerin yerini değiştirmekle yapıda meydana gelecek değişikliğin farkına varmış ve Halefü'l-Ahmer'in teklif ettiği alternatif ifade formunu, sırf anlatıma yansıtmak istediği değere, yakalamak istediği bedevî üslûba uygun olmadığı gerekçesiyle tercih etmemiştir. Daha önce Bloomfield'tan naklettiğimiz gibi: 'Biçim olarak farklı ifadelerin her zaman farklı anlamlara gelmesi hususu, iyi test edilmiş dilbilimsel bir hipotezdir.111

\footnotetext{
109 Hough, Style and Stylistics, s. 6.

110 Bekrî Şeyh Emin, el-Belagatü'l-Arabiyye, I. 41, 42.

111 Hough, Style and Stylistics, s. 4.
} 
Kelimeler ifadeye dönüștükten sonra içimizde bir takım duygular canlandırıp, zihnimize kimi düşünceler taşırlar. Bunlardan hareketle, kaynak birim hakkında bir dizi bilgiye ulaşma imkanı elde etmiş oluruz. Bunlar:

1. Yazarın sahip olduğu bilgi birikimi ve tecrübesinin yanı sıra, bunları elde edişi, içselleștirmesi, dönüştürmesi noktasındaki kapasitesini öğrenmiş oluruz.

2. Bu bilgi birikimi ve tecrübelerinden yeni düşünce ve anlamlar üretmesi noktasında yazarın sahip olduğu zeka kapasitesini de idrak ederiz. Böylece yazarın ne öğrendiği ve öğrettiği, kimden etkilendiği ve etkilediği, yeni ne getirdiği ve neyi taklit ettiğini anlamış oluruz.

3. Aynı şekilde, yazarın çevresiyle; yakın ve uzak çevresiyle girmiş olduğu etkileşimin gücünü kavrar, fikrî duruşunu ve psikolojik eğilimlerini öğrenmiş oluruz. Böylece yazarın zihniyet dünyası; bağlantıları, eğilimleri hatta biyolojik salgılarına varıncaya kadar bütün unsurlarıyla ortaya çımış olur. ${ }^{112}$

Üslûbun kaynak birim hakkında okura sunabileceği imkanlar dünyasına temas ettikten sonra, şu şekilde bir tanım teklifinde bulunabiliriz:

Üslûp, hedef birime vermek istediği mesajı en etkili ssekilde aktarabilmek için, kaynak birimin dilin ifade imkanlarını özgün ölçütlerle seçip kullanmak suretiyle anlatıma kattı̆̆ kişisel nitelikteki özelliklerin bütünüdür. Hough'un da belirttiği gibi, üslûbun tabiatına dair bakış açımız ne olursa olsun, şurası açıtır ki; üslûptan bahsederken esasen kastettiğimiz şey seçimdir; belirli bir dilin çeşitli kelime ve sözdizim imkanları arasından yapılan seçim. ${ }^{113}$

Bir yazarın üslûbunu çözümlemek, yazara ait bu özgün ölçütleri tespit etmek ve böylece anlatıma kattığı özellikleri ortaya koymakla mümkün olur. Bu unsurların okur üzerinde ne tür etkiler meydana getirebileceğini belirlemek de aynı şekilde üslûp analizinin bir parçasıdır.

112 el-Ma'tûk, "Mefûmu'l-üslûb", s.16.

113 Hough, Style and Stylistics, s. 8, 9. 